\title{
Alumino-oxy-rossmanite from pegmatites in Variscan metamorphic rocks from Eibenstein an der Thaya, Lower Austria, Austria: A new tourmaline that represents the most Al-rich end-member composition
}

\author{
Andreas Erte ${ }^{1, *}$, John M. Hughes ${ }^{2}$, Stefan Prowatke ${ }^{3,4}$, Thomas Ludwig ${ }^{4}$, Christian L. Lengauer ${ }^{1}$, \\ Hans-Peter Meyer ${ }^{4}$, Gerald Giester ${ }^{1, \dagger}$, Uwe Kolitsch ${ }^{1,5}$, ANd Albert Prayer ${ }^{6}$
}

\author{
${ }^{1}$ Institut für Mineralogie und Kristallographie, Geozentrum, Universität Wien, Althanstrasse 14, 1090 Wien, Austria \\ ${ }^{2}$ Department of Geology, University of Vermont, Burlington, Vermont 05405, U.S.A \\ ${ }^{3}$ D. Swarovski KG, Swarovskistrasse 30, 6112 Wattens, Austri \\ ${ }^{4}$ Institut für Geowissenschaften, Universität Heidelberg, Im Neuenheimer Feld 234-236, 69120 Heidelberg, Germany \\ ${ }^{5}$ Mineralogisch-Petrographische Abt., Naturhistorisches Museum, Burgring 7, 1010 Vienna, Austria \\ ${ }^{6}$ Sportplatzgasse 8, 3754 Irnfritz, Austria
}

\begin{abstract}
Alumino-oxy-rossmanite, ideally $\square \mathrm{Al}_{3} \mathrm{Al}_{6}\left(\mathrm{Si}_{5} \mathrm{AlO}_{18}\right)\left(\mathrm{BO}_{3}\right)_{3}(\mathrm{OH})_{3} \mathrm{O}$, is here described as a new member of the tourmaline supergroup. It is an early magmatic Al-rich oxy-tourmaline from a small pegmatitic body embedded in amphibolite and biotite-rich paragneiss. This new pink tourmaline was found in a Moldanubian pegmatite (of the Drosendorf Unit) that occurs in a large quarry near the village of Eibenstein an der Thaya, Waidhofen an der Thaya district, Lower Austria, Austria. The empirical formula of the holotype was determined on the basis of electron microprobe analysis (EMPA), secondary ion mass spectrometry (SIMS), spectroscopical methods (optical absorption and infrared spectroscopy), and crystal-structure refinement (SREF) as ${ }^{\mathrm{X}}\left(\square_{0.53} \mathrm{Na}_{0.46} \mathrm{Ca}_{0.01}\right){ }^{\mathrm{Y}}\left(\mathrm{Al}_{2.37} \mathrm{Mn}_{0.21}^{3+} \mathrm{Li}_{0.16} \square_{0.14}\right.$ $\left.\mathrm{Mn}_{0.07}^{2+} \mathrm{Fe}_{0.03}^{3+} \mathrm{Fe}_{0.01}^{2+} \mathrm{Ti}_{0.01}^{4+}\right){ }^{\mathrm{z}} \mathrm{Al}_{6}\left(\mathrm{Si}_{5.37} \mathrm{Al}_{0.41} \mathrm{~B}_{0.22} \mathrm{O}_{18}\right)\left(\mathrm{BO}_{3}\right)_{3}{ }^{\mathrm{v}}\left[(\mathrm{OH})_{2.77} \mathrm{O}_{0.23}\right]{ }^{\mathrm{w}}\left[\mathrm{O}_{0.80}(\mathrm{OH})_{0.15} \mathrm{~F}_{0.05}\right]$. Chemical composition (wt\%) is: $\mathrm{SiO}_{2} 33.96, \mathrm{TiO}_{2} 0.10, \mathrm{Al}_{2} \mathrm{O}_{3}$ 47.08, $\mathrm{B}_{2} \mathrm{O}_{3} 11.77, \mathrm{FeO} 0.08, \mathrm{Fe}_{2} \mathrm{O}_{3} 0.23, \mathrm{MnO}$ $0.52, \mathrm{Mn}_{2} \mathrm{O}_{3}$ 1.70, $\mathrm{CaO} 0.04, \mathrm{Li}_{2} \mathrm{O} 0.25, \mathrm{ZnO} 0.03, \mathrm{Na}_{2} \mathrm{O}$ 1.51, $\mathrm{H}_{2} \mathrm{O}$ 2.79, F 0.09, total 100.11. The presence of relatively high amounts of trivalent $\mathrm{Mn}$ in alumino-oxy-rossmanite is in agreement with the observation that the $\mathrm{OH}$ groups are present at a lower concentration than commonly found in other Al-rich and Li-bearing tourmalines. The crystal structure of alumino-oxy-rossmanite [space group $R 3 \mathrm{~m}$; $\left.a=15.803(1), c=7.088(1) \AA ; V=1532.9(3) \AA^{3}\right]$ was refined to an $R 1(F)$ value of $1.68 \%$. The eight strongest X-ray diffraction lines in the (calculated) powder pattern $[d$ in $\AA(I) h k l]$ are: 2.5534 (100) $051,3.9508$ (85) 220, 2.9236 (78) 122, 4.1783 (61) 211, 2.4307 (55) 012, 2.0198 (39) 152, 1.8995 (30) $342,6.294$ (28) 101. The most common associated minerals are quartz, albite, microcline, and apatite. Beryl and, in places, schorl are also found as primary pegmatitic phases. Because of the low mode of associated mica (muscovite), we assume that the silica melt, which formed this pegmatite, crystallized under relatively dry conditions, in agreement with the observation that alumino-oxy-rossmanite contains a lower amount of $\mathrm{OH}$ than most other tourmalines. This new member of the tourmaline supergroup exhibits the most Al-rich end-member composition of the tourmaline supergroup (theoretical content: $\left.\sim 54 \mathrm{wt} \% \mathrm{Al}_{2} \mathrm{O}_{3}\right)$. The significant content of tetrahedrally coordinated $\mathrm{Al}$ could reflect the relatively high-temperature conditions $\left(\sim 700^{\circ} \mathrm{C}\right)$ inferred for crystallization of the pegmatite.

Alumino-oxy-rossmanite was named for its chemical relationship to rossmanite, $\square\left(\mathrm{LiAl}_{2}\right) \mathrm{Al}_{6}\left(\mathrm{Si}_{6} \mathrm{O}_{18}\right)$ $\left(\mathrm{BO}_{3}\right)_{3}(\mathrm{OH})_{3}(\mathrm{OH})$, which in turn was named after George R. Rossman, Professor of Mineralogy at the California Institute of Technology (Pasadena, California, U.S.A.).

Keywords: Alumino-oxy-rossmanite, new mineral, Al-rich tourmaline, structure refinement, electron microprobe analysis, Moldanubian pegmatite, Eibenstein an der Thaya; Lithium, beryllium and boron: Quintessentially crustal
\end{abstract}

\section{INTRODUCTION AND PREVIOUS WORK}

The generalized formula of tourmaline-supergroup minerals can be written $\mathrm{XY}_{3} \mathrm{Z}_{6}\left(\mathrm{~T}_{6} \mathrm{O}_{18}\right)\left(\mathrm{BO}_{3}\right)_{3} \mathrm{~V}_{3} \mathrm{~W}$, as proposed by Henry et al. (2011). These authors and Hawthorne (1996, 2002) suggest

*E-mail: andreas.ertl@a1.net. Special collection papers can be found online at http://www.minsocam.org/MSA/AmMin/special-collections.html. $\dagger$ Orcid 0000-0002-3883-4188

Open access: Article available to all readers online. occupancies by the following most common cations:

$$
\begin{aligned}
& { }^{\mathrm{Ix}} \mathrm{X}=\mathrm{Na}^{+}, \mathrm{K}^{+}, \mathrm{Ca}^{2+}, \square \text { (vacancy) } \\
& { }^{\mathrm{v}} \mathrm{Y}=\mathrm{Fe}^{2+}, \mathrm{Mg}^{2+}, \mathrm{Mn}^{2+}, \mathrm{Al}^{3+}, \mathrm{Li}^{+}, \mathrm{Fe}^{3+}, \mathrm{Cr}^{3+}, \mathrm{V}^{3+} \\
& { }^{\mathrm{v}} \mathrm{Z}=\mathrm{Al}^{3+}, \mathrm{Mg}^{2+}, \mathrm{Fe}^{3+}, \mathrm{Cr}^{3+}, \mathrm{V}^{3+} \\
& { }^{\mathrm{IV}} \mathrm{T}=\mathrm{Si}^{4+}, \mathrm{Al}^{3+}, \mathrm{B}^{3+} \\
& \text { III } \mathrm{B}=\mathrm{B}^{3+} \\
& { }^{\mathrm{III}} \mathrm{V}=\mathrm{OH}^{-}, \mathrm{O}^{2-} \\
& { }^{\mathrm{II}} \mathrm{W}=\mathrm{OH}^{-}, \mathrm{F}^{-}, \mathrm{O}^{2-}
\end{aligned}
$$


Some of these cations can be present simultaneously on two and even three structural sites, reflecting order-disorder phenomena, mainly between the octahedral Y- and Z-site occupants (Ertl et al. 2003 and references therein). The tourmaline supergroup currently comprises 41 valid mineral species accepted by the Commission on New Minerals, Nomenclature and Classification (CNMNC) of the International Mineralogical Association (IMA). They represent hydroxyl-, fluor- and oxy-species of $\mathrm{X}$-site vacant, alkali, and calcic tourmalines with typical octahedral occupants like $\mathrm{Fe}^{2+}, \mathrm{Mg}^{2+}, \mathrm{Mn}^{2+}, \mathrm{Al}^{3+}, \mathrm{Li}^{+}, \mathrm{Fe}^{3+}, \mathrm{Cr}^{3+}$, and $\mathrm{V}^{3+}$ (Henry et al. 2011). Crystal-chemical relations in the tourmaline supergroup and the crystal chemistry of tourmalinesupergroup minerals have been investigated by many authors in the last 50 years (e.g., Donnay and Barton 1972; Povondra and Čech 1976; Deer et al. 1986; Foit 1989; Hawthorne et al. 1993; Hawthorne 1996, 2002, 2016; Henry and Dutrow 1996; Bloodaxe et al. 1999; Ertl et al. 2002, 2012a, 2012b, 2013, 2015, 2018; Hughes et al. 2011; Bosi and Lucchesi 2004, 2007; Bosi et al. 2004, 2013, 2015, 2017; Ertl and Tillmanns 2012; Ertl and Bačík 2020; Bačík and Fridrichová 2021). Tourmaline can also be a petrologic recorder of its geologic history as was demonstrated by Van Hinsberg et al. (2011).

Rossmanite, with the ideal end-member formula $\square\left(\mathrm{LiAl}_{2}\right)$ $\mathrm{Al}_{6}\left(\mathrm{Si}_{6} \mathrm{O}_{18}\right)\left(\mathrm{BO}_{3}\right)_{3}(\mathrm{OH})_{3}(\mathrm{OH})$, is an alkali-deficient tourmaline that was described as a new tourmaline species from Rožná, western Moravia, Czech Republic, by Selway et al. (1998). "Oxy-rossmanite", with the formula $\square\left(\mathrm{Li}_{0.5} \mathrm{Al}_{2.5}\right) \mathrm{Al}_{6}\left(\mathrm{Si}_{6} \mathrm{O}_{18}\right)$ $\left(\mathrm{BO}_{3}\right)_{3}(\mathrm{OH})_{3} \mathrm{O}$, was proposed as a hypothetical tourmaline endmember by Hawthorne and Henry (1999). This hypothetical tourmaline is characterized by a vacancy-dominated $\mathrm{X}$ site, an Al-dominated Y site (with a minor component of Li), and an O-dominated $\mathrm{W}$ site.

Here, we present the first natural occurrence of an even more aluminous end-member from Moldanubian pegmatites in Lower Austria. Additionally, we discuss the geological and petrological context of this unusual Al-rich tourmaline, which was recently given the new name alumino-oxy-rossmanite (IMA 2020-008b; Ertl et al. 2020). We also studied a second tourmaline sample (PINK2) of a more recent finding from this locality, since this tourmaline is close in composition to the holotype material of alumino-oxy-rossmanite (PINK1) to understand the significance of these Al-rich tourmalines.

\section{SAMPLE DESCRIPTION AND TYPE MATERIAL}

Tourmaline-bearing pegmatites from the western part of a quarry close to the village Eibenstein an der Thaya, Lower Austria, within the Moldanubian Drosendorf Unit with exposed marbles and amphibolites, were previously described by Götzinger et al. (1994). Subsequently, Ertl (1995) provided a more detailed description of these tourmalines. He characterized dravite, schorl, and colored Al-rich tourmaline (pale blue, pink, dark green). The Al-rich tourmaline was originally assigned to $\mathrm{Mn}$-/Fe-bearing olenite and elbaite, based on semiquantitative energy-dispersive X-ray spectroscopic analyses and the unit-cell parameters, which were in the range $a \approx 15.80-15.87$ and $c \approx$ 7.09-7.10 A. Ertl (1995) also characterized pale colored apatite, and beryl from the tourmaline-bearing pegmatite. Rare associated muscovite was also identified. Additional chemical, structural, and spectroscopic data of a pink tourmaline sample were given by Ertl et al. (2005). These authors demonstrated for the first time that it is possible to have significant amounts of both ${ }^{[4]} \mathrm{Al}$ and ${ }^{[4]} \mathrm{B}$ in an Al-rich tourmaline. They showed that this tourmaline has the highest known $\mathrm{Al}$ content of all natural tourmalines. Because of the dominant X-site vacancy, the O-dominant W site, and the Al-dominant $\mathrm{Y}$ site, this $\mathrm{Mn}$ - and Li-bearing tourmaline previously was assigned to "oxy-rossmanite" (Ertl et al. 2005), a hypothetical end-member in the proposed classification of tourmalines (Hawthorne and Henry 1999). However, the Mn content was only determined as $\mathrm{MnO}_{\text {total }}$ and $\mathrm{Li}$ was calculated in the optimized formula for a fully occupied Y site without allowing any Y-site vacancies.

In 2017 another, small tourmaline-bearing pegmatite was briefly exposed in the northern part of the aforementioned quarry near Eibenstein. The mineralogy of this lenticular, deformed, but more or less concordant pegmatite was studied in detail by Kolitsch et al. (2020). The main components are quartz, microcline, and albite; mica (muscovite) was present only in trace amounts. Black, tectonically deformed and fractured schorl crystals up to $20 \mathrm{~cm}$ were embedded in the outer part of the pegmatite body, while a small central, coarse-grained area contained macroscopically gray-pink to dark pinkish, prismatic tourmalines, assigned to olenite (according to two crystalstructure refinements and analyses by using scanning electron microscopy with energy-dispersive spectroscopy; Kolitsch et al. 2020). This pink tourmaline is generally overgrowing black to dark gray cores of Al-rich schorl, commonly with a narrow, pale to dark gray, smoky intermediate zone. The investigated olenitic tourmaline crystals exhibit lattice parameters of $a \approx 15.83$ and $c$ $\approx 7.10 \AA$ (for additional structural and chemical data see Kolitsch et al. 2020). Some of the pink tourmaline crystals, which reached lengths up to $2.5 \mathrm{~cm}$, were also tectonically deformed. They were bent, in part slightly broken and rehealed. Rarely, anhedral pink tourmaline fills very narrow $(\leq 1 \mathrm{~mm})$ cracks in black tourmaline or in feldspar or very small interstitial voids in feldspar. Beryl, fluorapatite (partly Mn-bearing), rutile, and columbite-(Mn) are present as macroscopic accessories in this pegmatite. Furthermore, mostly microscopic accessories (generally detected only in polished sections) include barite, bertrandite, bismuth, eulytine, hübnerite, pezzottaite(?), pollucite, scheelite, stibarsen, titanite, "uranmicrolite," as well as several unidentified phases, including a new Cs-Al-phosphate.

When in 1994 a small pegmatitic body (WGS84 N $48^{\circ}$ $\left.51^{\prime} 00^{\prime \prime} / \mathrm{E} 015^{\circ} 34^{\prime} 55^{\prime \prime}\right)$ was exposed in the aforementioned large quarry about $300 \mathrm{~m}$ northeast of the village Eibenstein an der Thaya (often named Hengl quarry after the operator), only one tourmaline crystal, intimately intergrown with quartz, was found, which contained a pink core zone ( $\sim 4 \mathrm{~mm}$ in diameter, $\sim 4 \mathrm{~mm}$ in length; Fig. 1) surrounded by a dark green rim. Parts of this pink tourmaline (now back in the collection of A.P.) were used as holotype material (sample PINK1). Recently in 2017, when another small pegmatitic body (WGS84 N 48 51'04"/ E $\left.015^{\circ} 34^{\prime} 57^{\prime \prime}\right)$ was exposed, more pink tourmaline was found. This time the crystals had prismatic forms. A part of the pink tourmaline crystal shown in Figure 2 was also characterized (sample PINK2). The most common associated minerals of pink tourmaline in both pegmatites are quartz, albite, microcline, and 


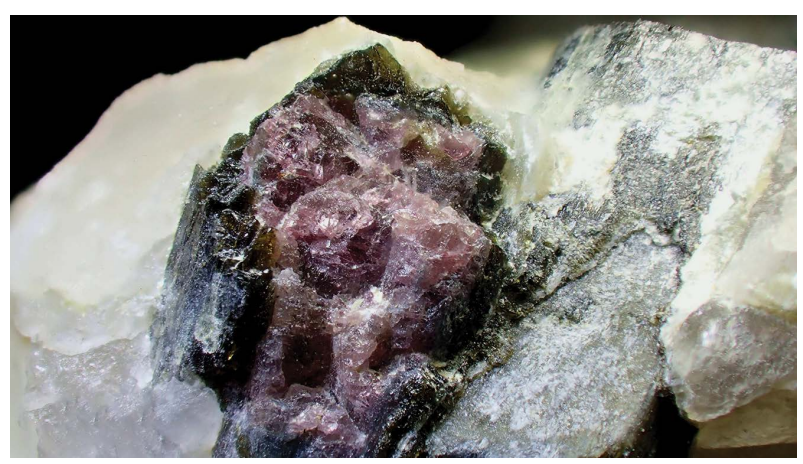

FigURE 1. Pink core of alumino-oxy-rossmanite (type material, PINK1) with a dark green rim of Fe-bearing alumino-oxy-rossmanite in quartz. Found in 1994 in the Hengl quarry, near the village Eibenstein an der Thaya, Lower Austria (photo detail $\sim 7 \times 13 \mathrm{~mm}^{2}$ ). Collection A.P.

fluorapatite. Schorl was more common in the 1994 pegmatite. In this pegmatite (type locality) alumino-oxy-rossmanite was early in the magmatic crystallization history, especially with respect to other tourmalines. Schorl is overgrowing aluminooxy-rossmanite while dravite (pale-green fibers) is the latest tourmaline in the crystallization sequence. The other magmatic phases quartz, albite, microcline, and fluorapatite are more or less co-genetic to alumino-oxy-rossmanite.

Part of the holotype specimen of alumino-oxy-rossmanite (sample PINK1) was deposited as sample NMNH 173824 at the National Museum of Natural History, Smithsonian Institution, Washington, D.C., as sample 134790 at the Mineralogical Museum, Harvard University, Cambridge, Massachusetts, and as sample 93533 at the Fersman Mineralogical Museum, Moscow, Russia. A piece of the type specimen, which was sent to the California Institute of Technology for optical spectroscopy studies is designated GRR2170 (polished section).

\section{REgIONAL GEOLOGY}

The Moldanubian Zone as the south-eastern part of the Bohemian Massif consists of a thick crystalline complex and exposes medium- to high-grade metamorphic rocks with Paleoproterozoic to Devonian protolith ages (Sorger 2020). The results of a comprehensive $P-T$ study by Sorger (2020) along four W-E trending profiles revealed a different distribution of metamorphic conditions within the Drosendorf Unit, a nappe in the Moldanubian Zone in the Bohemian massif (Petrakakis 1997; Lindner et al. 2020); this unit comprises the host rocks of the tourmaline-bearing pegmatites. The complex is characterized by an interlayering of partly migmatitic, garnet- and sillimanitebearing gneisses, quartzites, partially graphitic marbles, and calc-silicate rocks, amphibolites, and granitic orthogneisses. In general, a decreasing trend in metamorphic grade from southwest to northeast was observed. The Drosendorf Unit shows the highest temperature conditions of $\sim 800{ }^{\circ} \mathrm{C}$ in the south and the lowest of $650^{\circ} \mathrm{C}$ in the north (Sorger 2020). Metapelitic paragneisses, which are also the host rocks of the tourmaline-bearing pegmatites, from the southern Drosendorf Unit were affected by two metamorphic events. The first tectonothermal event of this unit was an early Variscan metamorphism in the Devonian at $\sim 370 \mathrm{Ma}$. After an intermittent phase of cooling and exhuma- tion, the Drosendorf was subjected to the predominant Variscan event in the Visean at $2340 \mathrm{Ma}$ (Sorger 2020). While the first metamorphism was pressure dominated, exhibited the second metamorphose a relatively high-geothermal gradient (Sorger 2020). In the Dosendorf Unit, usually the second metamorphic event was the more significant regionally widespread metamorphism. Pegmatites around Eibenstein an der Thaya were formed during the pressure release of the predominant Variscan event in the Visean at $\sim 340 \mathrm{Ma}$, e.g., a pegmatite containing tourmaline, topaz and cassiterite dated at $337 \pm 5 \mathrm{Ma}$ from a Sm-Nd garnetalbite isochron (Ertl et al. 2004). Low- $\mathrm{H}_{2} \mathrm{O}$ activities during the second event might be a consequence of aqueous fluid being driven off, which might have started already during the early Variscan metamorphism in the Devonian at $\sim 370$ Ma.

The pegmatitic body in which the new Al-rich tourmaline was found intruded into amphibolite and biotite paragneiss of the Drosendorf window. The Variscan metamorphic conditions for the Moldanubian rocks for this area of the Drosendorf nappe system are described as $0.4-0.8 \mathrm{GPa}, 680-750{ }^{\circ} \mathrm{C}$ (calculated by using pseudosections; Sorger 2020). Based on a map of that area contoured for temperature and pressure (Fig. 2.3 in Sorger 2020)

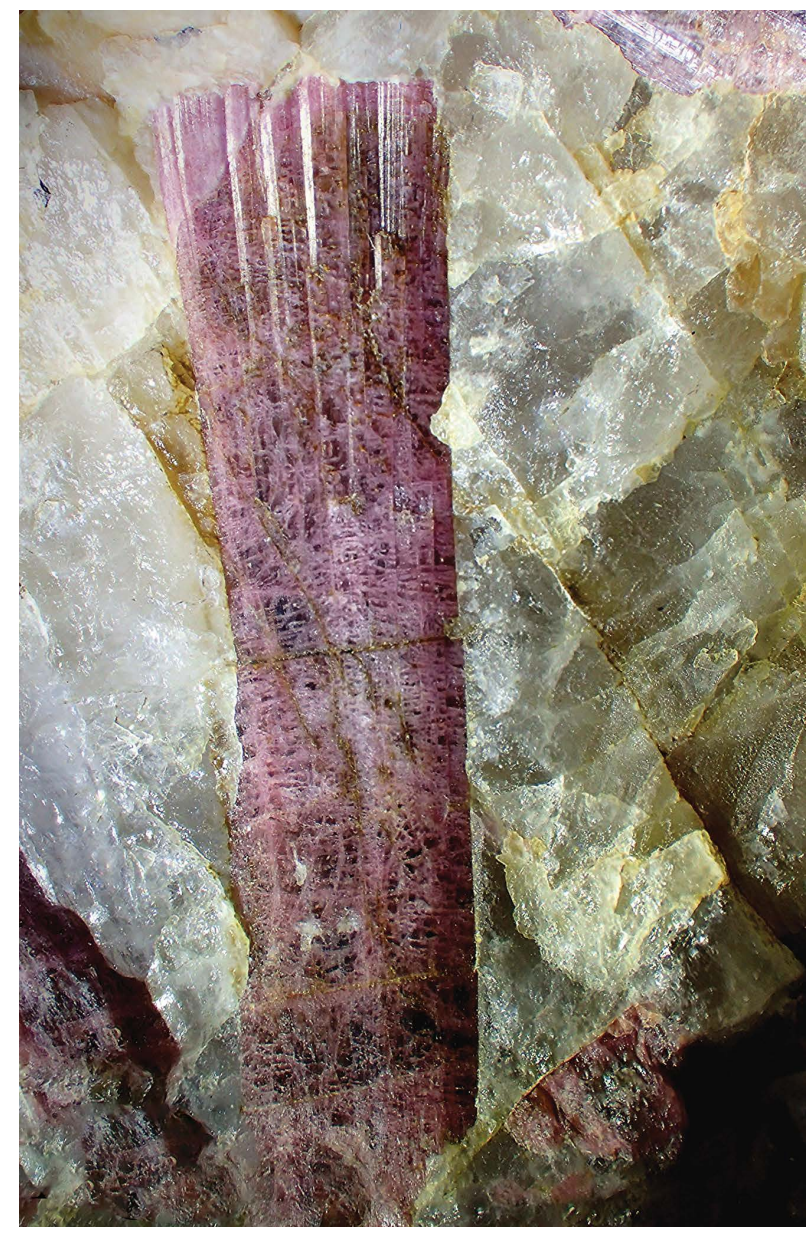

FIGURE 2. Pink tourmaline with a major alumino-oxy-rossmanite component (PINK2) in quartz. Found in 2017 in the Hengl quarry, near the village Eibenstein an der Thaya, Lower Austria (photo detail $\sim 15 \times 22$ $\mathrm{mm}^{2}$ ). Collection A.P. 
the metamorphic $P-T$ conditions during the predominant Variscan event for the Moldanubian rocks in the Hengl quarry, at the time when the pegmatites intruded, were $\sim 0.6 \mathrm{GPa}, \sim 700^{\circ} \mathrm{C}$. Several pegmatitic bodies occurred as vertically extended lenses with dimensions of up to $\sim 5 \times 3 \mathrm{~m}$ and a thickness of up to $\sim 50 \mathrm{~cm}$. Each lens included up to $\sim 5 \mathrm{~m}^{3}$ of coarse-grained pegmatitic rock. The pegmatites show a relatively sharp contact to their host rocks. Pegmatites hosted by a fine-grained biotite-rich paragneiss have a relatively sharp contact and a narrow chilled margin zone. Fine-grained black tourmaline in the intersection between pegmatite and host rock suggests that there had been some interaction between them.

\section{MATERIALS AND METHODS}

\section{Chemical analyses}

The two crystal fragments selected for crystal-structure determination (PINK1, from the 1994 pegmatite, and PINK2, from the 2017 pegmatite) were embedded in epoxy on a single $2.5 \mathrm{~cm}$ diameter round glass slide and polished. All elements reported here except $\mathrm{B}, \mathrm{Li}, \mathrm{Be}$, and $\mathrm{H}$ were determined with a Cameca SX51 electron microprobe (EMP) equipped with five wavelength-dispersive spectrometers (Universität Heidelberg). Operating conditions: $15 \mathrm{kV}$ accelerating voltage, $20 \mathrm{nA}$ beam current, and beam diameter $5 \mu \mathrm{m}$. Peaks for all elements were measured for $10 \mathrm{~s}$, except for $\mathrm{Mg}(20 \mathrm{~s}), \mathrm{Ti}(20 \mathrm{~s}), \mathrm{Zn}(30 \mathrm{~s})$, and $\mathrm{F}$ (40 s). We used the following (natural and synthetic) reference materals and X-ray lines for calibration: topaz $(\mathrm{F} K \alpha)$, albite $(\mathrm{Na} K \alpha)$, wollastonite $(\mathrm{Si} K \alpha)$ and $(\mathrm{Ca} K \alpha)$, corundum $(\mathrm{Al} K \alpha)$, periclase $(\mathrm{Mg} K \alpha)$, orthoclase $(\mathrm{K} K \alpha)$, rutile ( $\mathrm{Ti} K \alpha)$, rhodonite $(\mathrm{Mn} K \alpha)$, hematite ( $\mathrm{Fe} K \alpha)$, and gahnite $(\mathrm{ZnK \alpha})$. The analytical data were reduced and corrected using the PAP routine (Pouchou and Pichoir 1991). A modified matrix correction was applied assuming stoichiometric $\mathrm{O}$ atoms and all non-measured components as $\mathrm{B}_{2} \mathrm{O}_{3}$. The accuracy of the electron-microprobe analyses and the correction procedure was checked by measuring three samples of reference tourmalines (98114: elbaite, 108796: dravite, 112566: schorl). Compositions of these tourmaline samples were determined as part of an interlaboratory comparative study (Dyar et al. 1998, 2001). Under the described conditions, the accuracy of all analyses is $\pm 1 \%$ relative for major elements and $\pm 5 \%$ relative for minor elements.

$\mathrm{H}, \mathrm{Li}$, and $\mathrm{B}$ were determined in PINK2 by SIMS with a CAMECA ims $3 \mathrm{f}$ ion microprobe (Universität Heidelberg). Primary $\mathrm{O}^{-}$ions were accelerated to $10 \mathrm{keV}$. The mass spectrometer's energy window width was $40 \mathrm{eV}$. An offset of $75 \mathrm{~V}$ was applied to the secondary accelerating voltage of $4.5 \mathrm{kV}$ so that secondary ions with an initial energy of $75 \pm 20 \mathrm{eV}$ were analyzed (energy filtering), which minimizes potential matrix effects (Ottolini et al. 1993). The primary current was $10 \mathrm{nA}$, resulting in a spot diameter of $\sim 20 \mu \mathrm{m}$. The spectrometer's mass resolving power (MRP) $\mathrm{M} / \Delta \mathrm{M}$ for $\mathrm{B}, \mathrm{Li}$, and $\mathrm{Si}$ was set to $\sim 1000(10 \%)$ to suppress interferences $\left({ }^{6} \mathrm{LiH}^{+}\right.$, $\left.{ }^{10} \mathrm{BH}^{+}, \mathrm{Al}^{3+}\right)$. Secondary ${ }^{7} \mathrm{Li},{ }^{11} \mathrm{~B}$, and ${ }^{30} \mathrm{Si}$ ions were collected under an imaged field of $150 \mu \mathrm{m}$ diameter. For $\mathrm{H}$ (and $\mathrm{Si}$ ) the MRP M/ $/ \mathrm{M}$ was set to $\sim 400(10 \%)$, and the imaged field was limited to a diameter of $\sim 12 \mu \mathrm{m}$. In situ water contamination was reduced by using a liquid nitrogen cold-trap attached to the sample chamber (Ludwig and Stalder 2007; and references therein). The count rates of the analyzed isotopes $\left({ }^{1} \mathrm{H},{ }^{7} \mathrm{Li}\right.$, and $\left.{ }^{11} \mathrm{~B}\right)$ were normalized to the count rate of ${ }^{30} \mathrm{Si}$ and relative ion yields (RIY) were used for quantification of the results (e.g., Hinton 1990, 1995; Ottolini et al. 1993). The analytical procedures for the SIMS analyses (which included Be) of sample PINK1 were almost identical (details see Ertl et al. 2005).

The relative ion yields for $\mathrm{H}$ and $\mathrm{B}$ were determined using three tourmalines as reference material: elbaite, dravite and schorl (Dyar et al. 1998, 2001). The reference material for $\mathrm{Li}$ and Be was the NIST SRM610 standard glass with concentrations for $\operatorname{Li}\left(464.2 \mu \mathrm{g} \mathrm{g}^{-1}\right)$ and $\mathrm{Be}\left(469.0 \mu \mathrm{g} \mathrm{g}^{-1}\right)$ average taken from Pearce et al. (1997). The relative reproducibility $(1 \sigma)$ for the RIY of $\mathrm{H}, \mathrm{Li}, \mathrm{Be}$, and $\mathrm{B}$ was $<1 \%$. Matrix effects and the uncertainty of the element concentrations in the reference material limit the accuracy of the analysis. The relative accuracy is estimated to be $<20 \%$ for $\mathrm{H}$ and $<10 \%$ for $\mathrm{Li}, \mathrm{Be}$, and $\mathrm{B}$. Table 1 contains complete chemical analyses of the two studied crystal fragments of pink Al-rich tourmaline.

\section{Powder X-ray diffraction}

The eight strongest X-ray diffraction lines in the (calculated) powder pattern $[d$ in $\AA(I) h k l]$ are: $2.5534(100) 051,3.9508$ (85) 220, $2.9236(78) 122,4.1783$ (61) 211, 2.4307 (55) 012, 2.0198 (39) 152, 1.8995 (30) 342, 6.294 (28) 101 (Online
TABLE 1. Composition of pink tourmaline from the Hengl Quarry, Eibenstein an Der Thaya, Lower Austria

\begin{tabular}{lcc}
\hline Constituent & $\begin{array}{c}\mathrm{PINK}^{\mathrm{a}} \\
\mathrm{wt} \%\end{array}$ & $\begin{array}{c}\mathrm{PINK2}^{\mathrm{b}} \\
\mathrm{wt} \%\end{array}$ \\
\hline $\mathrm{SiO}_{2}$ & $33.96(28)$ & $33.82(36)$ \\
$\mathrm{TiO}_{2}$ & $0.10(3)$ & $0.17(2)$ \\
$\mathrm{Al}_{2} \mathrm{O}_{3}$ & $47.08(16)$ & $45.71(36)$ \\
$\mathrm{B}_{2} \mathrm{O}_{3}$ & $11.77(12)$ & 12.12 \\
$\mathrm{FeO}_{\text {total }}$ & $0.29(8)$ & $0.07(2)$ \\
$\mathrm{FeO}^{c}$ & 0.08 & 0.02 \\
$\mathrm{Fe}_{2} \mathrm{O}_{3} \mathrm{c}$ & 0.23 & 0.06 \\
$\mathrm{MnO}_{\text {total }}$ & $2.05(9)$ & $2.33(19)$ \\
$\mathrm{MnO}^{\mathrm{C}}$ & 0.52 & 0.61 \\
$\mathrm{Mn}_{2} \mathrm{O}_{3}{ }^{\mathrm{c}}$ & 1.70 & 1.92 \\
$\mathrm{CaO}$ & $0.04(2)$ & $0.09(1)$ \\
$\mathrm{Li}_{2} \mathrm{O}$ & $0.25(1)$ & 0.46 \\
$\mathrm{ZnO}$ & $0.03(1)$ & $0.02(1)$ \\
$\mathrm{Na} \mathrm{C}_{2} \mathrm{O}$ & $1.51(5)$ & $1.84(4)$ \\
$\mathrm{H}_{2} \mathrm{O}$ & $2.79^{\mathrm{d}}$ & $2.90^{\mathrm{e}}$ \\
$\mathrm{F}$ & $0.09(2)$ & $0.43(10)$ \\
$\mathrm{O} \equiv \mathrm{F}$ & -0.04 & -0.18 \\
$\mathrm{Total}$ & 100.11 & 100.00 \\
\hline
\end{tabular}

a Type material of alumino-oxy-rossmanite from 1994 pegmatite; average of 25 EMP analyses and average of two SIMS analyses for $\mathrm{B}_{2} \mathrm{O}_{3}, \mathrm{Li}_{2} \mathrm{O}, \mathrm{BeO}$, and $\mathrm{H}_{2} \mathrm{O}$. $\mathrm{BeO}=9 \mu \mathrm{g} / \mathrm{g}, \mathrm{H}_{2} \mathrm{O}=2.98(9) \mathrm{wt} \%$.

${ }^{\mathrm{b}}$ Tourmaline from 2017 pegmatite (details see text); average of $20 \mathrm{EMP}$ analyses and 1 SIMS analysis for $\mathrm{B}_{2} \mathrm{O}_{3}, \mathrm{Li}_{2} \mathrm{O}$, and $\mathrm{H}_{2} \mathrm{O}$.

'Valence states were estimated by applying the Beer's Law $\varepsilon$ value to the optical absorption spectrum (details see text).

${ }^{d}$ Weight percent calculated from optimal site occupancies (details see Ertl et al. 2015). e This value was calculated to produce a Total sum of $100 \%$. The measured SIMS value of $\mathrm{H}_{2} \mathrm{O}$ was $3.37 \mathrm{wt} \%$ (one analysis). Hence, the calculated value is within an error of $14 \%$ in good agreement with the measured value and with other observed data (further details see text).

Materials ${ }^{1}$ Table OM1). The X-ray powder diffraction pattern had to be calculated because only a very small amount of material was available for scientific studies of the single small pink tourmaline crystal, which was originally found in 1994. Although pink tourmaline was found more frequently in the 2017 pegmatite, the chemistry of the studied crystals was not as close to the ideal end-member as that of the 1994 material.

\section{Crystal-structure refinement}

A fragment of the holotype crystal (PINK1) was mounted on a Bruker Apex CCD X-ray diffractometer equipped with graphite-monochromatized MoKa radiation (Department of Geology, Miami University, Oxford, Ohio, U.S.A.). Redundant data were collected for an approximate sphere of reciprocal space, and were integrated and corrected for Lorentz and polarization factors, and for absorption, using the Bruker program SaintPlus (Bruker AXS 2001). The structure was refined with the Bruker SHELXTL v. 6.10 package of programs, with neutral-atom scattering factors and terms for anomalous dispersion.

A fragment of PINK2 was structurally investigated at the Institut für Mineralogie und Kristallographie, Geozentrum, Universität Wien, Austria. As a first step, the quality of different crystal fragments was checked with a Bruker APEXII diffractometer equipped with a CCD area detector and an Incoatec Microfocus Source $\mathrm{I} \mu \mathrm{S}(30 \mathrm{~W}$, multilayer mirror, $\mathrm{MoK \alpha})$. The crystal with the best diffracting quality was subsequently measured on this diffractometer. Single-crystal X-ray diffraction intensity data, up to $82.84^{\circ} 2 \theta$, were collected at room temperature, integrated, and corrected for Lorentz and polarization factors, and with a multi-scan absorption correction (Sheldrick 2002). The structure was refined with SHELXL-97 (Sheldrick 2008) using scattering factors for neutral atoms.

The refinements were performed with anisotropic displacement parameters for all non-hydrogen atoms. The various site occupancies were refined according to well-known characteristics of the tourmaline structure (Henry et al. 2011) and considering the results of the EMP, SIMS, and spectroscopic analyses. Hence, the $\mathrm{X}$-site occupancy was refined using a Na scattering factor, the $\mathrm{Y}$ site with $\mathrm{Al}$ and Li scattering factors, the $\mathrm{T}$ site with $\mathrm{Si}$ and $\mathrm{B}$, and the $\mathrm{Al}$ occupancy at the $\mathrm{Z}$ site was fixed at 1.00 , typical for Al-rich tourmalines. The $\mathrm{W}$ site was preliminarily refined with $\mathrm{O}$ vs. $\mathrm{F}$ scattering factors, but because the resulting value for $\mathrm{F}$ was lower than the standard deviation, in the final cycles the $\mathrm{W}$ site was only refined with $\mathrm{O}$ scattering factors.

Refined unit-cell parameters and the most important average bond lengths 
TABLE 2. Selected structural data (Å) of Al-rich oxy-tourmaline from the Hengl Quarry, Eibenstein an Der Thaya, Lower Austria

\begin{tabular}{lrr}
\hline & PINK1 $^{\mathrm{a}}$ & \multicolumn{1}{c}{$\mathrm{PINK2}^{\mathrm{b}}$} \\
\hline $\mathrm{a}$ & $15.803(1)$ & $15.809(1)$ \\
$\mathrm{C}$ & $7.088(1)$ & $7.082(1)$ \\
$\langle\mathrm{X}-\mathrm{O}\rangle$ & $2.687(2)$ & $2.680(1)$ \\
$\langle\mathrm{Y}-\mathrm{O}\rangle$ & $1.962(1)$ & $1.970(1)$ \\
$\langle\mathrm{Z}-\mathrm{O}\rangle$ & $1.908(1)$ & $1.907(1)$ \\
$\langle\mathrm{T}-\mathrm{O}\rangle$ & $1.619(1)$ & $1.617(1)$ \\
\hline a Type material of alumino-oxy-rossmanite; pink tourmaline (with a major & \\
alumino-oxy-rossmanite component) from 1994 pegmatite. & \\
b Pink tourmaline from 2017 pegmatite (details see text). & \\
\hline
\end{tabular}

for PINK1 and PINK2 are listed in Table 2. The CIF ${ }^{1}$ provides crystal data and details of both structure refinements (atomic coordinates, individual bond lengths, and angles)

\section{Optical spectroscopy}

A $380 \times 185 \mu \mathrm{m}^{2}$ crystal fragment of the holotype PINK1 was prepared as a $92.8 \mu \mathrm{m}$ thick parallel plate polished on both sides to study its color properties. Polarized optical absorption spectra in the $390-1100 \mathrm{~nm}$ range were obtained at about $1 \mathrm{~nm}$ resolution with a locally built microspectrometer system consisting of a 1024-element Si diode-array detector coupled to a grating spectrometer system via fiber optics to a highly modified NicPlan infrared microscope containing a calcite polarizer. A pair of conventional $10 \times$ objectives was used as an objective and a condenser. Spectra were obtained through the central area of the sample, which included a veil of two-phase (liquid/gas) inclusions.

\section{Infrared spectra}

Infrared spectra of holotype material to examine the $\mathrm{OH}$ content were measured in the main compartment of a Nicolet Magna 860 FTIR spectrometer at $2 \mathrm{~cm}^{-1}$ resolution using a $200 \mu \mathrm{m}$ aperture. Near-IR spectra were obtained using a $\mathrm{CaF}_{2}$ beam splitter, tungsten-halogen source, MCT-A detector, and $\mathrm{LiIO}_{3}$ polarizer and were averaged over 256 to 4000 scans. For the smallest crystal fragments, a silica beam splitter and InSb detector were used to collect the spectra. Additional spectra were obtained with a Nicolet Continuum infrared microscope using a $\mathrm{MCT}-\mathrm{A} / \mathrm{CaF}_{2} /$ tungsten-halogen combination.

The total integrated band area $\left(\operatorname{area}_{t 0 t}=\operatorname{area}_{\mathrm{E} \mid c}+2 \times \operatorname{area}_{\mathrm{ELc}}\right)$ was determined for the mid-IR OH overtone bands using Omnic E.S.P. 5.2 software. Integrated absorbances were determined by establishing a suitable baseline and measuring the area between the curve and the baseline over the region of the $\mathrm{OH}$ bands. The baseline connects with the spectral trace on both the high- and low-energy side of the $\mathrm{OH}$ region. This was done on a spectrum normalized for a $1 \mathrm{~cm}$ thick crystal. Before integration, a minor, visually estimated background correction was needed to compensate for a sloping background.

\section{Results AND Discussion}

\section{Physical properties}

Holotype alumino-oxy-rossmanite is brittle and has a Mohs hardness of 7; it is non-fluorescent, has no observable parting and cleavage, and has a vitreous luster. The megascopic color of alumino-oxy-rossmanite is pink, and the streak is white. It has a measured density of $3.07(3) \mathrm{g} / \mathrm{cm}^{3}$ (pycnometer method; Syromyatnikov 1935; Ksanda and Merwin 1939) and a calculated density of $3.092(1) \mathrm{g} / \mathrm{cm}^{3}$ based on the empirical formula and the unit-cell volume refined from the single-crystal X-ray diffraction data. The fracture is conchoidal. The mineral has a prismatic habit, but only crude prismatic forms are developed. Twinning was not observed.

\section{Optical spectroscopy and optical properties}

The optical absorption spectrum of alumino-oxy-rossmanite (Fig. 3 ) is most intense in the $\mathrm{E} \perp \mathrm{c}$ direction. It consists of a band at about $555 \mathrm{~nm}$ and weaker features near 450 and $415 \mathrm{~nm}$. The E\|c spectrum also contains the $555 \mathrm{~nm}$ band that overlaps with another broad band near $475 \mathrm{~nm}$. There is also an indication of a weak band near $780 \mathrm{~nm}$. The broad rise in absorption from high- to low-energy could be due in part to scattering from imperfections in the crystal, and partly to an ultraviolet absorption band. The spectrum is broadly similar to the spectrum of rossmanite (Ertl et al. 2005), but the major bands are shifted to longer wavelengths. For example, in rossmanite, the main band is observed at $517 \mathrm{~nm}$.

The pink color of alumino-oxy-rossmanite is due to the band at $555 \mathrm{~nm}$ that is associated with $\mathrm{Mn}^{3+}$ probably produced by natural irradiation of $\mathrm{Mn}^{2+}$ as has been previously described for elbaite (Reinitz and Rossman 1988). In plane-polarized light, alumino-oxy-rossmanite is pleochroic, $\mathrm{O}=$ pink, $\mathrm{E}=$ nearcolorless (polarized parallel to the c-axis; orientation: $\mathrm{E} \| \mathrm{c}$ ). Alumino-oxy-rossmanite is uniaxial negative, $\omega=1.648(5)$, $\varepsilon$ $=1.628(5)(590 \mathrm{~nm})$.

\section{Infrared spectroscopy}

The infrared spectrum obtained in the mid-infrared region (Fig. 4) of sample PINK1 shows $\mathrm{OH}$ bands in the E\|c spectrum at $7175,7144,7022, \sim 6964 \mathrm{~cm}^{-1}$, and the most prominent band at $6708 \mathrm{~cm}^{-1}$. These bands are shifted to lower wavenumbers as compared to the corresponding bands in fluor-elbaite of similar divalent-cation composition (Ertl et al. 2005). Mattson (1985)

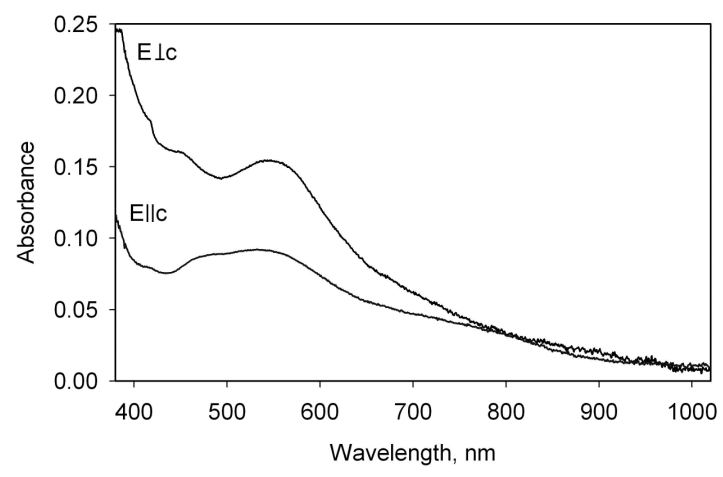

FigURE 3. Optical absorption spectrum of a $0.0928 \mathrm{~mm}$ thick crystal of alumino-oxy-rossmanite (sample PINK1).

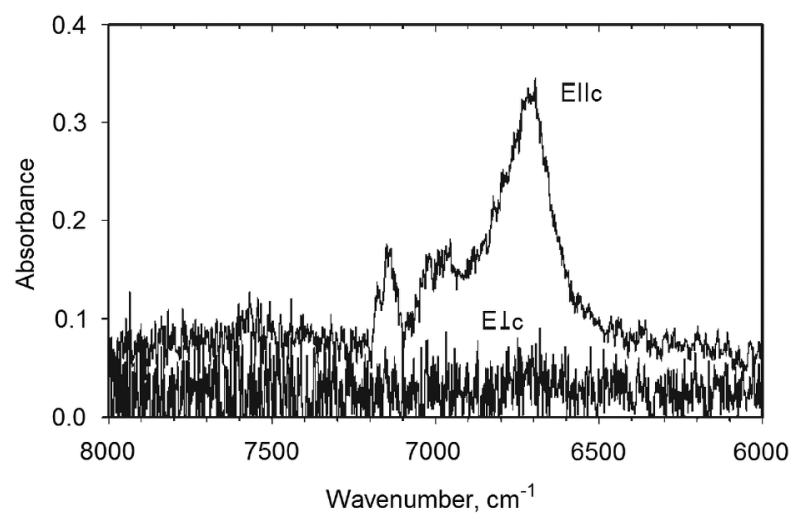

FigUre 4. Near-infrared spectrum of alumino-oxy-rossmanite (sample PINK1) from Eibenstein in the $\mathrm{OH}$ overtone region. A spectrum of a $0.0928 \mathrm{~mm}$ thick crystal was plotted normalized to $1.0 \mathrm{~mm}$ thickness. 
concluded that the $7001 \mathrm{~cm}^{-1}$ band in an elbaitic tourmaline (sample GRR 598-Afgh-1) is associated with $\mathrm{H}$ bound to the $\mathrm{O} 3$ site with a local configuration involving $\mathrm{Li}^{+}$. This band is of low intensity in alumino-oxy-rossmanite compared to the elbaitic tourmaline of Mattson (1985). The low intensity of these $\mathrm{OH}$ bands suggests that the absolute $\mathrm{OH}$ concentration is lower than that in sample GRR 598-Afgh-1. Because no absolute calibration of the intensity of the $\mathrm{OH}$ overtone bands in the tourmaline spectrum has yet been done, it is not possible at this time to establish an absolute concentration. By comparing the $\mathrm{OH}$ intensity of alumino-oxy-rossmanite to other relevant tourmalines (25 elbaites, fluor-elbaites, fluor-liddicoatites, and rossmanites), alumino-oxy-rossmanite remains the tourmaline with integrated intensity that is signifiantly lower than all the other tourmaline samples (Ertl et al. 2015). All of these observations are highly suggestive that alumino-oxy-rossmanite contains a lower amount of $\mathrm{OH}$ than most other tourmalines. The infrared spectrum confirms that hydroxyl groups in holotype alumino-oxy-rossmanite (sample PINK1) are present at a lower concentration than commonly found in other Li-bearing tourmalines.

By applying the Beer's Law $\varepsilon$ value (estimated to be 7.5 for $\mathrm{Mn}^{3+}$; Reinitz and Rossman 1988) to the optical absorption spectrum (Fig. 2) and by determination of the $\mathrm{Mn}^{3+}$ band heights, considering the chemistry and the density (3.09) of aluminooxy-rossmanite, we were able to estimate the percentage of $\mathrm{Mn}$, which was oxidized to $\mathrm{Mn}^{3+}(\sim 74 \%)$. Because iron is oxidized under less oxidizing conditions than manganese, which is shown in Figure 3 of Huebner (1969), we consider the percentage of the oxidized Fe to be similar, if not higher than it is for Mn. It is not uncommon that the small amount of total Fe in pink Al-rich and Li-bearing tourmalines is oxidized to a relatively high percentage ( $\sim 60-90 \%$ as determined by Mössbauer spectroscopy; Ertl et al. 2010). The oxidation of relatively high amounts of $\mathrm{Mn}$ and $\mathrm{Fe}$ in alumino-oxy-rossmanite is in agreement with the observation that the $\mathrm{OH}$ groups are present at a lower concentration than commonly found in other Al-rich and Li-bearing tourmalines.

\section{Crystal structure}

The crystal structure of alumino-oxy-rossmanite [holotype material, sample PINK1; space group $R 3 m ; a=15.803(1)$, $\left.c=7.088(1) \AA ; V=1532.8(3) \AA^{3}\right]$ was refined to an $R 1(F)$ value of $1.68 \%$. The crystal structure of tourmaline sample PINK2 $\left[a=15.809(1), c=7.082(1) \AA ; V=1532.9(3) \AA^{3}\right]$ was refined to an $R 1(F)$ value of $1.37 \%$. The empirical formulas of these samples were determined on the basis of EMPA, SIMS, spectroscopical methods (optical absorption and infrared spectroscopy), and SREF as follows:

PINK 1: ${ }^{\mathrm{X}}\left(\square_{0.53} \mathrm{Na}_{0.46} \mathrm{Ca}_{0.01}\right)^{\mathrm{Y}}\left(\mathrm{Al}_{2.37} \mathrm{Mn}_{0.21}^{3+} \mathrm{Li}_{0.16} \square_{0.14} \mathrm{Mn}_{0.07}^{2+}\right.$ $\left.\mathrm{Fe}_{0.03}^{3+} \mathrm{Fe}_{0.01}^{2+} \mathrm{Ti}_{0.01}^{4+}\right){ }^{\mathrm{z}} \mathrm{Al}_{6}\left(\mathrm{Si}_{5.37} \mathrm{Al}_{0.41} \mathrm{~B}_{0.22} \mathrm{O}_{18}\right)\left(\mathrm{BO}_{3}\right)_{3}{ }^{\mathrm{v}}\left[(\mathrm{OH})_{2.77} \mathrm{O}_{0.23}\right]$ ${ }^{\mathrm{w}}\left[\mathrm{O}_{0.80}(\mathrm{OH})_{0.15} \mathrm{~F}_{0.05}\right]$

PINK2: ${ }^{\mathrm{x}}\left(\mathrm{Na}_{0.56} \square_{0.42} \mathrm{Ca}_{0.02}\right)^{\mathrm{Y}}\left(\mathrm{Al}_{2.18} \mathrm{Li}_{0.29} \mathrm{Mn}_{0.23}^{3+} \square_{0.19} \mathrm{Mn}_{0.08}^{2+}\right.$ $\left.\mathrm{Ti}_{0.02}^{4+} \mathrm{Fe}_{0.01}^{3+}\right){ }^{\mathrm{z}} \mathrm{Al}_{6}\left(\mathrm{Si}_{5.35} \mathrm{Al}_{0.34} \mathrm{~B}_{0.31} \mathrm{O}_{18}\right)\left(\mathrm{BO}_{3}\right)_{3} \quad \mathrm{v}\left[(\mathrm{OH})_{2.90} \mathrm{O}_{0.10}\right]$ ${ }^{\mathrm{w}}\left[\mathrm{O}_{0.63} \mathrm{~F}_{0.21}(\mathrm{OH})_{0.16}\right]$

No $\mathrm{H}$ could be found at the W site (O1 site) by refinement, and also the difference-Fourier map around the $\mathrm{W}$ site indicates this site to be mainly occupied by $\mathrm{O}$. The map shows a spherical electron density similar to that described by Cámara et al. (2002) [Fig. 1a of that paper, crystal 1 , dravite, with $0.18(\mathrm{OH})$ at the W site]. Because of a small, but still visible $\mathrm{OH} 1$ band in the IR spectrum, only $0.15(\mathrm{OH})$ pfu have therefore been assigned to the W site. Ertl et al. (2002) showed that the bond-angle distortion $\left(\sigma_{\text {oct }}^{2}\right)$ of the $\mathrm{ZO}_{6}$ octahedron in a tourmaline is largely a function of the $<\mathrm{Y}-\mathrm{O}>$ distance of that tourmaline, although the occupant of the $\mathrm{O} 3$ site (V site) also affects that distortion. For all investigated tourmalines in which the $\mathrm{V}$ site is completely occupied by $3(\mathrm{OH})$ groups, including the samples from Hughes et al. (2004), the covariance, $r$, of $<\mathrm{Y}-\mathrm{O}>$ and the $\sigma_{\text {oct }}^{2}$ of the $\mathrm{ZO}_{6}$ octahedron is -0.991 (Fig. 5). In Figure 5, the data of the holotype material (PINK1) of alumino-oxy-rossmanite lies between the tourmalines that contain $3(\mathrm{OH})$ at the $\mathrm{V}$ site and natural fluor-buergerite, which contains $0.3(\mathrm{OH})$ and $2.7 \mathrm{O}$ at the $\mathrm{V}$ site. In addition, the tourmaline sample PINK2 is slightly shifted in the direction of $\mathrm{OH}$-poor fluor-buergerite. The calculated wt $\%$ for $\mathrm{H}_{2} \mathrm{O}$ is $\sim 14 \%$ lower than the measured value (by SIMS) for sample PINK2. One possible explanation for the higher value as obtained by SIMS is that alumino-oxy-rossmanite contains $\mathrm{H}_{2} \mathrm{O}$-bearing fluid inclusions (Ertl et al. 2005). However, these errors are still lower than the relative uncertainty of the SIMS analyses.

The structural refinement of the $\mathrm{X}$ site of the type material (PINK1) confirms an occupancy of $\mathrm{Na}<50 \%$ (only very small amounts of $\mathrm{Ca}$ were found by chemical analyses; Table 1). Only Al was found to occupy the $\mathrm{Z}$ site, and also the refined Y-site occupancies are in good agreement with the chemistry (Table 1). Although the structure refinements show significant amounts of ${ }^{[4]} \mathrm{B}[0.28(1)-0.33(2)$ apfu], the $<\mathrm{T}-\mathrm{O}>$ bond lengths are in the range 1.617(1)-1.619(1) $\AA$ (Table 2), which is, within the standard deviation, close to a $\mathrm{T}$ site fully occupied with $\mathrm{Si}$ (MacDonald and Hawthorne 1995; Bloodaxe et al. 1999; Bosi et al. 2005). Because of a relatively low-Si content in both samples ( 5.4 apfu Si; Table 1), these bond-lengths can only be explained by significant amounts of ${ }^{[4]} \mathrm{Al}$ in addition to ${ }^{[4]} \mathrm{B}$.

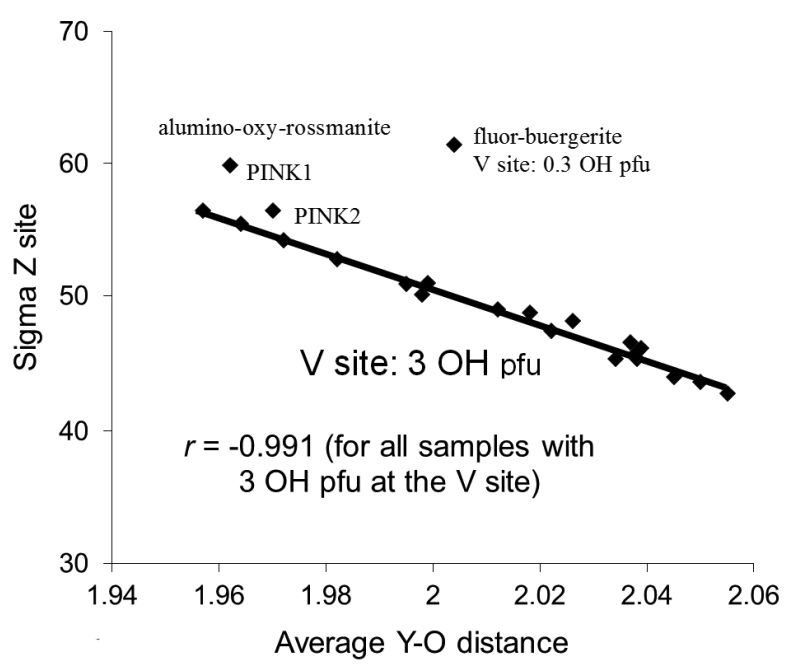

FIGURE 5. Relationship between bond-angle distortion $\sigma_{\text {oct }}^{2}$ of the $\mathrm{ZO}_{6}$ octahedron and the average $\mathrm{Y}-\mathrm{O}$ distance. Modified from Figure 3 from Ertl et al. (2002), including the structural data from Hughes et al. (2004). Alumino-oxy-rossmanite (type material, PINK1), Al-rich oxytourmaline (with a major alumino-oxy-rossmanite component, PINK2). 
A substitution of Si by Al in tourmaline was described for the first time by Foit and Rosenberg (1979). The type material of alumino-oxy-rossmanite (sample PINK1) contains 0.41 apfu ${ }^{[4]} \mathrm{Al}^{3+}$. The simplified T-site occupation can also be written as $\left(\mathrm{R}_{5}^{4+} \mathrm{R}^{3+}\right)$ or as $\left[\mathrm{Si}_{5}^{4+}(\mathrm{Al}, \mathrm{B})^{3+}\right]$. Hence, alumino-oxy-rossmanite is an Al-rich tourmaline that contains not only Si but also significant amounts of $\mathrm{B}$ and $\mathrm{Al}$ at the $\mathrm{T}$ site. Elbaitic and olenitic tourmaline samples from pegmatites often contain ${ }^{[4]} \mathrm{B}$ as well as ${ }^{[4]} \mathrm{Al}(\mathrm{Ertl}$ et al. 2007, 2009, 2010; Lussier et al. 2009).

The lattice parameters of both investigated samples are among the lowest observed among natural tourmalines, also lower than other samples from this locality (Kolitsch et al. 2020). Alumino-oxy-rossmanite has the highest known Al content of all natural tourmalines (up to $47.08 \mathrm{wt} \% \mathrm{Al}_{2} \mathrm{O}_{3}$; up to 8.78 apfu Al). Very high-Al contents were also found in colorless olenite from Koralpe, Styria, Austria [up to 46.53-46.71 wt\% $\mathrm{Al}_{2} \mathrm{O}_{3}$ and 8.46 apfu Al (Ertl et al. 1997; Hughes et al. 2000)], and in olenite from the type locality Olenii Range, Voron'i Tundry, Kola Peninsula, Russia [up to $45.79-46.43 \mathrm{wt} \% \mathrm{Al}_{2} \mathrm{O}_{3}$ and 8.52 apfu Al (Sokolov et al. 1986; Schreyer et al. 2002)]. Every tourmaline can be described very well by the mol\% of different end-members, like every garnet. Considering the endmember formula of alumino-oxy-rossmanite (see next section), the major components of sample PINK1 (holotype material) are $41 \mathrm{~mol} \%$ alumino-oxy-rossmanite, $33 \mathrm{~mol} \%$ olenite, and $9 \mathrm{~mol} \%$ elbaitic tourmaline (fluor-elbaite, elbaite). The sum of these components is $83 \mathrm{~mol} \%$. The major components of sample PINK2 are $34 \mathrm{~mol} \%$ alumino-oxy-rossmanite, $28 \mathrm{~mol} \%$ olenite, and $19 \mathrm{~mol} \%$ elbaitic tourmaline, and hence this sample is a complex intergrowth of different end-members, mainly of the alumino-oxy-rossmanite-olenite solid solution. The sum of these components is $81 \mathrm{~mol} \%$. Minor components in both samples are fluor-liddicoatite and tsilaisite with $\leq 3 \mathrm{~mol} \%$. The rest of the cations cannot yet be assigned to a special tourmaline because there is no end-member established, which includes $\mathrm{Mn}^{3+}$ or ${ }^{\mathrm{T}} \mathrm{B}$. We conclude that in both samples, alumino-oxy-rossmanite is the dominant component. In contrast to PINK1, sample PINK2 is characterized by a lower alumino-oxy-rossmanite component and a higher elbaitic component.

\section{End-member formula and relationship to other tourmalines}

The empirical formula of the holotype material, calculated on the basis of $31(\mathrm{O}, \mathrm{OH}, \mathrm{F})$, is ${ }^{\mathrm{X}}\left(\square_{0.53} \mathrm{Na}_{0.46} \mathrm{Ca}_{0.01}\right){ }^{\mathrm{Y}}\left(\mathrm{Al}_{2.37} \mathrm{Mn}_{0.21}^{3+}\right.$ $\left.\mathrm{Li}_{0.16} \square_{0.14} \mathrm{Mn}_{0.07}^{2+} \mathrm{Fe}_{0.03}^{3+} \mathrm{Fe}_{0.01}^{2+} \mathrm{Ti}_{0.01}^{4+}\right){ }^{\mathrm{z}} \mathrm{Al}_{6}\left(\mathrm{BO}_{3}\right)_{3}\left(\mathrm{Si}_{5.37} \mathrm{Al}_{0.41} \mathrm{~B}_{0.22} \mathrm{O}_{18}\right)$ $\mathrm{v}\left[(\mathrm{OH})_{2.77} \mathrm{O}_{0.23}\right]^{\mathrm{W}}\left[\mathrm{O}_{0.80}(\mathrm{OH})_{0.15} \mathrm{~F}_{0.05}\right]$.

Details of the occupation of both $(\mathrm{OH}) / \mathrm{O}$ sites are given in the Crystal structure section above. The simplified formula is $(\square, \mathrm{Na})$ $(\mathrm{Al}, \mathrm{Mn}, \mathrm{Li}, \square)_{3} \mathrm{Al}_{6}\left(\mathrm{BO}_{3}\right)_{3}\left[(\mathrm{Si}, \mathrm{Al}, \mathrm{B})_{6} \mathrm{O}_{18}\right][(\mathrm{OH}), \mathrm{O}]_{3}[\mathrm{O},(\mathrm{OH})]$. When applying the IMA-CNMNC recommended use of the dominant-valency rule for tourmaline-supergroup minerals, the Y-site cations are ordered as follows: $(\mathrm{Al}, \mathrm{Mn}, \mathrm{Fe})_{2.6}^{3+}>(\mathrm{Li})_{0.2}^{+}>$ $(\mathrm{Mn}, \mathrm{Fe})_{0.1}^{2+}$, that is $\mathrm{R}_{2.6}^{3+}>\mathrm{R}_{0.2}^{+}>\mathrm{R}_{0.1}^{2+}$. Hence, our new tourmaline corresponds to the "X-site vacant tourmaline group" (Henry et al. 2011). The most abundant cation at the $Y$ site with the charge $3+$ is aluminum: $\mathrm{Al}_{2.4}^{3+}>\mathrm{Mn}_{0.2}^{3+}>\mathrm{Fe}_{<0.1}^{3+}$.

If we use the empirical formula and apply the site total charge approach (Bosi et al. 2019), which is useful for iden- tifying new tourmaline end-members, two configurations are possible:

$$
\begin{aligned}
& \mathrm{Y}=+8 \text { and } \mathrm{T}=+24 \\
& \mathrm{Y}=+9 \text { and } \mathrm{T}=+23.2
\end{aligned}
$$

In accord with the chemical composition of the $\mathrm{Y}$ and $\mathrm{T}$ sites of the studied sample, the possible atomic arrangements are quantitatively evaluated in terms of apfu as follows:

\section{Configuration 1.}

(a) ${ }^{\mathrm{Y}}\left(\mathrm{R}_{2}^{3+} \mathrm{R}^{2+}\right)^{\Sigma 8+}{ }^{\mathrm{T}}\left(\mathrm{R}_{6}^{4+}\right)^{\Sigma 24+}={ }^{\mathrm{Y}}\left(\mathrm{R}_{2}^{3+} \mathrm{R}^{2+}\right)_{0.08}{ }^{\mathrm{T}}\left(\mathrm{R}_{6}^{4+}\right)_{0.08}={ }^{\mathrm{Y}}\left(\mathrm{Al}_{0.16}^{3+} \mathrm{R}_{0.08}^{2+}\right)$ ${ }^{\mathrm{T}}\left(\mathrm{Si}_{0.48}^{4+}\right)=0.72$ apfu, limited by the $\mathrm{R}^{2+}$ content;

(b) ${ }^{\mathrm{Y}}\left(\mathrm{R}_{2.5}^{3+} \mathrm{R}_{0.5}^{+}\right)^{\Sigma 8+\mathrm{T}}\left(\mathrm{R}_{6}^{4+}\right)^{\Sigma 24+}={ }^{\mathrm{Y}}\left(\mathrm{R}_{2.5}^{3+} \mathrm{R}_{0.5}^{+}\right)_{0.32}{ }^{\mathrm{T}}\left(\mathrm{R}_{6}^{4+}\right)_{0.32}={ }^{\mathrm{Y}}\left(\mathrm{Al}_{0.80}^{3+} \mathrm{Li}_{0.16}^{+}\right)$ ${ }^{\mathrm{T}}\left(\mathrm{Si}_{1.92}^{4+}\right)=2.88$ apfu, limited by the Li content.

(c) ${ }^{\mathrm{Y}}\left(\mathrm{R}_{8 / 3}^{3+} \square_{1 / 3}\right)^{\Sigma 8+\mathrm{T}}\left(\mathrm{R}_{6}^{4+}\right)^{\Sigma 24+}={ }^{\mathrm{Y}}\left(\mathrm{R}_{8 / 3}^{3+} \square_{1 / 3}\right)_{0.42}{ }^{\mathrm{T}}\left(\mathrm{R}_{6}^{4+}\right)_{0.42}={ }^{\mathrm{Y}}\left(\mathrm{Al}_{1.12}^{3+} \square_{0.14}\right)$ ${ }^{\mathrm{T}}\left(\mathrm{Si}_{2.52}^{4+}\right)=3.78$ apfu, limited by the number of vacancies.

Configuration 2. Only the following end-member charge arrangement is in agreement with configuration 2 :

$$
{ }^{\mathrm{x}} \square^{\mathrm{Y}}\left(\mathrm{R}_{3}^{3+}\right)^{\Sigma 9+}{ }^{\mathrm{Z}} \mathrm{Al}_{6}\left[{ }^{\mathrm{T}}\left(\mathrm{R}_{5}^{4+} \mathrm{R}^{3+}\right)^{\Sigma 23+} \mathrm{O}_{18}\left(\mathrm{BO}_{3}\right)_{3}{ }^{\mathrm{v}}(\mathrm{OH})_{3}{ }^{\mathrm{w}} \mathrm{O}\right.
$$

In the studied sample, the arrangement compatible with the Y-site and T-site constituents are: ${ }^{\mathrm{Y}}\left(\mathrm{R}_{3}^{3+}\right)^{59+}{ }^{\mathrm{T}}\left(\mathrm{R}_{5}^{4+} \mathrm{R}^{3+}\right)^{\Sigma 23+}=$ ${ }^{\mathrm{Y}}\left(\mathrm{R}_{3}^{3+}\right)_{0.87}{ }^{\mathrm{T}}\left(\mathrm{R}_{5}^{4+} \mathrm{R}^{3+}\right)_{0.87}={ }^{\mathrm{Y}}\left(\mathrm{Al}_{2.61}^{3+}\right)^{\mathrm{T}}\left(\mathrm{Si}_{4.35}^{4+} \mathrm{R}_{0.87}^{3+}\right)=7.83 \mathrm{apfu}$, limited by ${ }^{\mathrm{T}} \mathrm{R}^{3+}$ contents. Actually, this arrangement is limited by the $\square$ content at the $X$ site ( 0.53 vacancies pfu), and consequently the actual number of atoms decreases to 4.77 apfu. We assume that the measured contents of $\mathrm{B}$ and $\mathrm{Li}$ are reasonably accurate, because the excess $\mathrm{B}(\mathrm{B}>3.00 \mathrm{apfu})$ as well as the $\mathrm{Li}$ content are relatively small. Hence, we conclude that ${ }^{\mathrm{T}} \mathrm{Al}>{ }^{\mathrm{T}} \mathrm{B}$. When we use the empirical formula, the amount of the end-member charge arrangement of configuration 2 is the largest one, and since ${ }^{\mathrm{T}} \mathrm{Al}>$ ${ }^{\mathrm{T}} \mathrm{B}$, the end-member formula of the studied sample can be written as $\square \mathrm{Al}_{3} \mathrm{Al}_{6}\left(\mathrm{BO}_{3}\right)_{3}\left(\mathrm{Si}_{5} \mathrm{AlO}_{18}\right)(\mathrm{OH})_{3} \mathrm{O}$. This ideal formula requires $\mathrm{SiO}_{2} 31.90, \mathrm{Al}_{2} \mathrm{O}_{3}$ 54.14, $\mathrm{B}_{2} \mathrm{O}_{3} 11.09, \mathrm{H}_{2} \mathrm{O} 2.87$, total $100 \mathrm{wt} \%$.

Hawthorne and Henry (1999) were the first to propose "oxyrossmanite," with the ideal formula $\square\left(\mathrm{Li}_{0.5} \mathrm{Al}_{2.5}\right) \mathrm{Al}_{6}\left(\mathrm{Si}_{6} \mathrm{O}_{18}\right)$ $\left(\mathrm{BO}_{3}\right)_{3}(\mathrm{OH})_{3} \mathrm{O}$, as a hypothetical tourmaline end-member, because of its relationship to rossmanite (Selway et al. 1998). While rossmanite contains an $(\mathrm{OH})$ at the W site, "oxy-rossmanite" contains an oxygen $\left(\mathrm{O}^{2-}\right)$ at this site. Because the new tourmaline contains not only more $\mathrm{Al}$, which fills the $\mathrm{Y}$ and $\mathrm{Z}$ sites entirely and the Si site partially, than "oxy-rossmanite," but also $\mathrm{O}^{2-}$ at the $\mathrm{W}$ site, we suggest the name alumino-oxy-rossmanite, with the end-member formula $\square \mathrm{Al}_{3} \mathrm{Al}_{6}\left(\mathrm{BO}_{3}\right)_{3}\left(\mathrm{Si}_{5} \mathrm{AlO}_{18}\right)(\mathrm{OH})_{3} \mathrm{O}$. Alumino-oxy-rossmanite is named for its chemical relationship to rossmanite, $\square\left(\mathrm{LiAl}_{2}\right) \mathrm{Al}_{6}\left(\mathrm{Si}_{6} \mathrm{O}_{18}\right)\left(\mathrm{BO}_{3}\right)_{3}(\mathrm{OH})_{3}(\mathrm{OH})$, which in turn was named after George R. Rossman, Professor of Mineralogy at the California Institute of Technology (Pasadena, California). With the proposed name, it is evident how this endmember is related to the quite common tourmaline rossmanite and to "oxy-rossmanite." We also want to keep the tourmaline nomenclature as simple as possible so that the name already gives some information about the composition.

How the theoretical chemical composition of aluminooxy-rossmanite is related to the tourmalines rossmanite, "oxy-rossmanite," elbaite, fluor-elbaite, darrellhenryite, olenite, 
TABLE 3. Chemical compositions and unit-cell parameters of aluminooxy-rossmanite compared with IMA-approved Al-rich and Li-bearing tourmalines

\begin{tabular}{|c|c|c|c|c|c|c|}
\hline & 1 & 2 & 3 & 4 & 5 & 6 \\
\hline $\mathrm{SiO}_{2}$ & 33.96 & 38.10 & 37.08 & 37.48 & 38.38 & 37.70 \\
\hline $\mathrm{Al}_{2} \mathrm{O}_{3}$ & 47.08 & 44.60 & 38.37 & 37.81 & 43.49 & 37.90 \\
\hline $\mathrm{B}_{2} \mathrm{O}_{3}$ & 11.77 & 10.88 & 10.81 & 10.83 & 11.01 & 10.89 \\
\hline $\mathrm{Li}_{2} \mathrm{O}$ & 0.25 & 1.13 & 1.59 & 1.58 & 1.63 & 2.48 \\
\hline $\mathrm{Na}_{2} \mathrm{O}$ & 1.51 & 1.43 & 2.58 & 2.51 & 1.92 & 0.88 \\
\hline $\mathrm{CaO}$ & 0.04 & - & 0.42 & 0.34 & 0.05 & 4.21 \\
\hline $\mathrm{H}_{2} \mathrm{O}$ & 2.99 & 3.70 & 3.03 & 3.03 & 2.86 & 2.69 \\
\hline$F$ & 0.09 & 0.20 & 0.62 & 1.49 & 0.71 & 1.72 \\
\hline $\mathrm{TiO}_{2}$ & 0.10 & - & 0.03 & - & - & 0.38 \\
\hline $\mathrm{FeO}$ & 0.29 & - & 2.99 & 3.39 & - & 0.83 \\
\hline $\mathrm{MnO}$ & 2.05 & - & 1.39 & 2.09 & 0.02 & 0.27 \\
\hline $\mathrm{MgO}$ & - & - & 0.03 & - & - & 0.11 \\
\hline $\mathrm{K}_{2} \mathrm{O}$ & - & - & 0.31 & 0.06 & - & - \\
\hline$a(\AA ̊)$ & 15.803 & 15.770 & 15.882 & 15.893 & 15.823 & 15.867 \\
\hline$c(\AA)$ & 7.088 & 7.085 & 7.122 & 7.122 & 7.095 & 7.135 \\
\hline$V\left(\AA^{3}\right)$ & 1532.9 & 1525.9 & 1555.8 & 1558.0 & 1538.4 & 1555.7 \\
\hline
\end{tabular}

Notes: 1 = pink alumino-oxy-rossmanit from the Hengl quarry, Eibenstein, Lower Austria (PINK1, this work); 2 = pale pink rossmanite, type locality Rožná, Czech Republic (Selway et al. 1998); 3 = green elbaite, Dolní Bory, Czech Republic (Povondra et al. 1985); 4 = green fluor-elbaite, type locality Cruzeiro mine, Minas Gerais, Brazil (Bosi et al. 2013); 5 = pale pink darrellhenryite, type locality Nová Ves, Czech Republic (Novák et al. 2013); 6 = fluor-liddicoatite, type locality near Antsirabe, Madagascar (Dunn et al. 1977).

fluor-liddicoatite, and liddicoatite is shown in Online Materials ${ }^{1}$ Table OM2. For further comparison, chemical analyses and selected physical properties of the valid species of Li-bearing tourmaline end-members of the tourmaline supergroup (Henry et al. 2011) are given in Table 3. The comparison shows that alumino-oxy-rossmanite and rossmanite have the smallest unit-cell parameters of all these species. The derivation of alumino-oxy-rossmanite from rossmanite appears to be a two-step process, as shown in plots in Figures 6 and 7. The second step involves the T sites, which is unique to alumino-oxy-rossmanite among tourmalines. For example, ${ }^{\mathrm{Y}} \mathrm{Li}_{0.5}+{ }^{\mathrm{V}} \mathrm{OH}$ in rossmanite $=$ ${ }^{\mathrm{Y}} \mathrm{Al}_{0.5}+{ }^{\mathrm{V}} \mathrm{O}$ in "oxy-rossmanite" while Si remains equal to 6 . In contrast, ${ }^{\mathrm{Y}} \mathrm{Al}_{0.5}+{ }^{\mathrm{T}} \mathrm{Al}$ in alumino-oxy-rossmanite $={ }^{\mathrm{Y}} \mathrm{Li}_{0.5}+{ }^{\mathrm{T}} \mathrm{Si}$ in "oxy-rossmanite," that is, the T site is involved. Ignoring the changes in Si occupancy results in the two analyzed tourmaline samples (PINK1 and PINK2) plotting between end-member "oxy-rossmanite" and end-member olenite and not between end-member alumino-oxy-rossmanite and end-member "oxyrossmanite." This omission is overcome by having two plots side-by-side (see Figs. 6 and 7).

\section{IMPLICATIONS}

The new tourmaline alumino-oxy-rossmanite represents the most Al-rich end-member composition of all tourmalines. Because the sixfold-coordinated sites were mainly occupied by $\mathrm{Al}^{3+}$, other sites must have appropriate charges to produce a charge-balanced formula. The choices are cation vacancies at the $\mathrm{X}$ site, trivalent cations at the $\mathrm{T}$ site, and an $\mathrm{O}$-for-OH substitution at the $\mathrm{OH}$ sites. We have learned in our study that all three of these possibilities are observed in alumino-oxy-rossmanite. The tourmaline structure seems to be flexible enough for Al to occupy not only the $\mathrm{Y}$ and $\mathrm{Z}$ sites simultaneously, but also to occupy part of the $\mathrm{T}$ site. A T-site occupancy with $\left(\mathrm{Si}_{5} \mathrm{Al}\right)$, as was written in the theoretical end-member formula of aluminooxy-rossmanite, seems to mark the highest possible amount of Al that can be included at this site (see also Ertl et al. 2018).

Tetrahedrally coordinated B increases with decreasing tem- perature at pressures below pressures of $\sim 1000-1500 \mathrm{MPa}$ (Ertl et al. 2008, 2012a, 2018). In contrast, ${ }^{[4]} \mathrm{Al}$ often increases with increasing temperature (Henry and Dutrow 1996). A possible explanation for the observation that ${ }^{[4]} \mathrm{Al}>{ }^{[4]} \mathrm{B}$ in this early magmatic tourmaline, could be that $\mathrm{Al}^{3+}$ is favored by the relatively high-temperature conditions of $\sim 700{ }^{\circ} \mathrm{C}$ (Sorger 2020) during the formation of these Moldanubian pegmatites. Alumino-oxyrossmanite contains up to $\sim 0.4$ apfu ${ }^{[4]} \mathrm{Al}$. It is not uncommon for high-grade metamorphic rocks (upper-amphibolite to granulitefacies) to contain tourmaline with up to 0.4 apfu ${ }^{[4]} \mathrm{Al}$ (e.g., Grew et al. 1990, 1997; Henry and Dutrow 1996). This is also in agreement with another Al-rich oxy-tourmaline with tetrahedrally

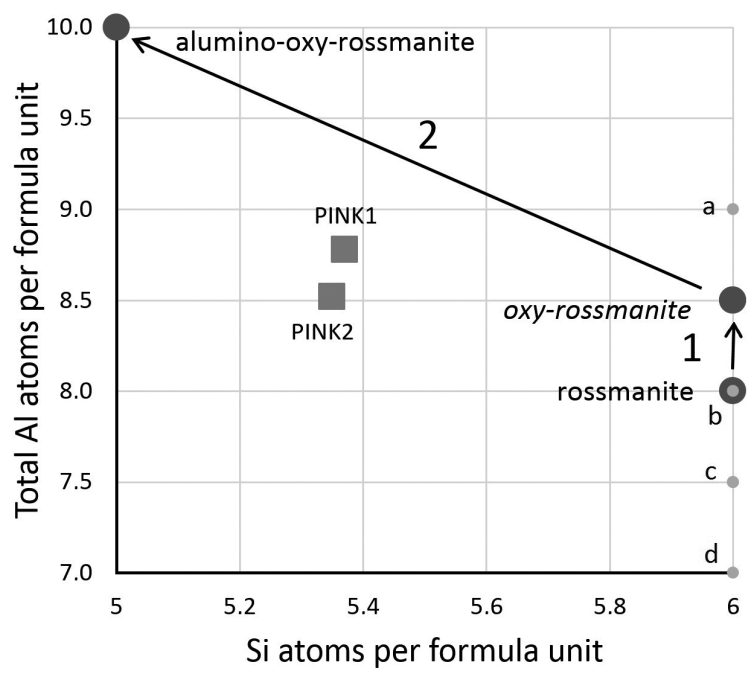

Figure 6. Total Al vs. Si in different Al-rich tourmaline endmembers. Note: $\mathrm{a}=$ Olenite; $\mathrm{b}=$ Darrellhenryite; $\mathrm{c}=$ Elbaite, fluorelbaite; $d$ = Fluor-liddicoatite. Measured samples: PINK1 = Aluminooxy-rossmanite (type material); PINK2 = Pink tourmaline with a major alumino-oxy-rossmanite component.

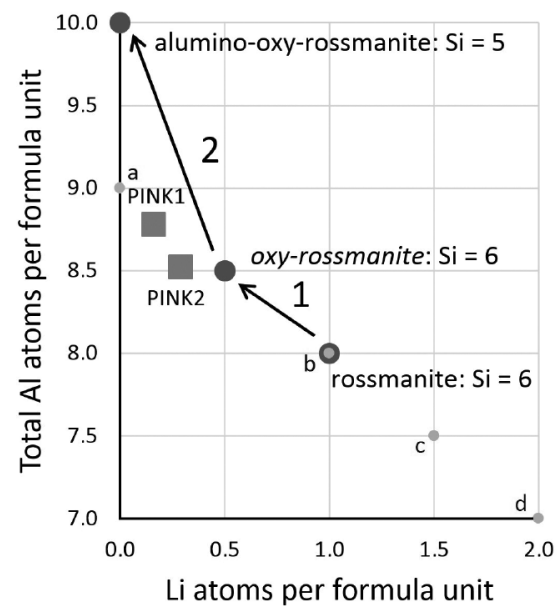

Figure 7. Total Al vs. Li in Al-rich tourmaline end-members. Note: $\mathrm{a}=$ Olenite; $\mathrm{b}=$ Darrellhenryite; $\mathrm{c}=$ Elbaite, fluor-elbaite; $\mathrm{d}=$ Fluorliddicoatite. Measured samples: PINK1 = Alumino-oxy-rossmanite (type material); PINK2 = Pink tourmaline with a major alumino-oxyrossmanite component. 
coordinated $\mathrm{Al}$ from small bodies of abyssal pegmatite located in the eastern part of the Moldanubian Zone, Bohemian Massif, Czech Republic (Cempírek et al. 2006).

Alumino-oxy-rossmanite was formed during relatively dry conditions of the pegmatitic melt, reflected by the low quantity of associated mica (muscovite) and the occurrence of oxytourmalines, which are linked to low $a \mathrm{H}_{2} \mathrm{O}$. Although the amount of muscovite also depends on the availability of Al, which would appear to be relatively high given the tourmaline composition, it is possible that it in turn could reflect high B with tourmaline sequestering the $\mathrm{Al}$ and thereby prohibiting other aluminous minerals from forming (Van Hinsberg and Schumacher 2007).

A major implication of such a temperature-sensitive T-site occupancy could be the development of a geothermometer. More investigations of tourmaline in petrologically well-characterized rocks and synthesis experiments are necessary for the exact understanding of the temperature dependence of the tourmaline T-site occupancy. We conclude that, in our opinion, the presence of alumino-oxy-rossmanite is indicative of high-temperature conditions in a relatively dry environment, which is poor in $\mathrm{Li}$ and $\mathrm{F}$.

\section{ACKNOWLEDGMents AND Funding}

We thank Andreas Wagner, University of Vienna, Austria, for preparing the tourmaline samples. We are also thankful to Ralf Schuster and Manfred Linner, both from the Geological Survey of Austria (Vienna), and to Gerlinde Habler (Department of Lithospheric Research, Vienna) for helpful discussions and references. The constructive comments from Associate Editor Edward S. Grew (University of Maine, Orono), as well as from reviewers Vincent van Hinsberg (McGill University, Montreal), and Peter Bačík (Comenius University, Bratislava) were very helpful to improve this work. This study was supported by the Austrian Science Fund (FWF) project no. P 31049-N29 (A.E.).

\section{REFERENCES CITED}

Bačík, P., and Fridrichová, J. (2021) Cation partitioning among crystallographic sites based on bond-length constraints in tourmaline-supergroup minerals. American Mineralogist, 106, 851-861. https://doi.org/10.2138/am-2021-7804.

Bloodaxe, E.S., Hughes, J.M., Dyar, M.D., Grew, E.S., and Guidotti, C.V. (1999) Linking structure and chemistry in the schorl-dravite series. American Mineralogist, 84, 922-928. https://doi.org/10.2138/am-1999-5-627.

Bosi, F., and Lucchesi, S. (2004) Crystal chemistry of the schorl-dravite series. European Journal of Mineralogy, 16, 335-344. https://doi.org/10.1127/0935$1221 / 2004 / 0016-0203$

(2007) Crystal chemical relationships in the tourmaline group: structural constraints on chemical variability. American Mineralogist, 92, 1054-1063. https://doi.org/10.2138/am.2007.2370.

Bosi, F., Lucchesi, S., and Reznitskii, L. (2004) Crystal chemistry of the dravitechromdravite series. European Journal of Mineralogy, 16, 345-352. doi: 10.1127/0935-1221/2004/0016-0345.

Bosi, F., Andreozzi, G.B., Federico, M., Graziani, G., and Lucchesi, S. (2005) Crystal chemistry of the elbaite-schorl series. American Mineralogist, 90, 1784-1792. https://doi.org/10.2138/am.2005.1827.

Bosi, F., Skogby, H., Hålenius, U., and Reznitskii, L. (2013) Crystallographic and spectroscopic characterization of Fe-bearing chromo-alumino-povondraite and its relations with oxy-chromium-dravite and oxy-dravite. American Mineralogist, 98, 1557-1564. https://doi.org/10.2138/am.2013.4447.

Bosi, F., Andreozzi, G.B., Hålenius, U., and Skogby, H. (2015) Experimental evidence for partial $\mathrm{Fe}^{2+}$ disorder at the $\mathrm{Y}$ and $\mathrm{Z}$ sites of tourmaline: A combined EMP, SREF, MS, IR and OAS study of schorl. Mineralogical Magazine, 79, 515-528. https://doi.org/10.1180/minmag.2015.079.3.01.

Bosi, F., Cámara, F., Ciriotti, M.E., Hålenius, U., Reznitskii, L., and Stagno, V. (2017) Crystal chemical relations and classification problems of tourmalines belonging to the oxy-schorl-oxy-dravite-bosiite-povondraite series. European Journal of Mineralogy, 29, 445-455. doi: 10.1127/ejm/2017/0029-2616.

Bosi, F., Biagioni, C., and Oberti, R. (2019) On the chemical identification and classification of minerals. Minerals, 9, 591. https://doi.org/10.3390/min9100591.

Cámara, F., Ottolini, L., and Hawthorne, F.C. (2002) Chemistry of three tourmalines by SREF, EMPA, and SIMS. American Mineralogist, 87, 1437-1442. https:// doi.org/10.2138/am-2002-1021.

Cempírek, J., Novák, M., Ertl, A., Hughes, J.M., Rossman, G.R., and Dyar, M.D. (2006) Fe-bearing olenite with tetrahedrally coordinated Al from an abyssal pegmatite of the Bohemian massif at Kutná Hora: Structure, crystal chemistry, and optical spectra. Canadian Mineralogist, 44, 23-30. https://doi.org/10.2113/ gscanmin.44.1.23.

Deer, W.A., Howie, R.A., and Zussman, J. (1986) Rock-forming Minerals. Vol. 1B: Disilicates and Ring Silicates, 2nd ed. Longman.

Donnay, G., and Barton, R. Jr. (1972) Refinement of the crystal structure of elbaite and the mechanism of tourmaline solid solution. Tschermaks Mineralogische Und Petrographische Mitteilungen, 18, 273-286. https://doi.org/10.1007/ BF01082837.

Dunn, P.J., Appleman, D.E., and Nelen, J.E. (1977) Liddicoatite, a new calcium end-member of the tourmaline group. American Mineralogist, 62, 1121-1124.

Dyar, M.D., Taylor, M.E., Lutz, T.M., Francis, C.A., Guidotti, C.V., and Wise, M. (1998) Inclusive chemical characterization of tourmaline: Mössbauer study of Fe valence and site occupancy. American Mineralogist, 83, 848-864. https:// doi.org/10.2138/am-1998-7-817.

Dyar, M.D., Wiedenbeck, M., Robertson, D., Cross, L.R., Delaney, J.S., Ferguson, K., Francis, C.A., Grew, E.S., Guidotti, C.V., Hervig, R.L., and others (2001) Reference minerals for the microanalysis of light elements. Geostandards and Geoanalytical Research, 25, 441-463. https://doi.org/10.1111/j. 1751-908X.2001.tb00616.x.

Ertl, A. (1995) Elbait, Olenit, Dravit-Buergerit-Mischkristalle, Dravit, Uvit und ein neuer Al-Turmalin (?) von österreichischen Fundstellen. Mitteilungen Der Österreichischen Mineralogischen Gesellschaft, 140, 55-72.

Ertl, A., and Bačík, P. (2020) Considerations about Bi and Pb in the crystal structure of Cu-bearing tourmaline. Minerals, 10, 706. https://doi.org/10.3390/ $\min 10080706$.

Ertl, A., and Tillmanns, E. (2012) The [9]-coordinated X site in the crystal structure of tourmaline-group minerals. Zeitschrift Für Kristallographie, 227, 456-459. https://doi.org/10.1524/zkri.2012.1486.

Ertl, A., Pertlik, F., and Bernhardt, H.-J. (1997) Investigations on olenite with excess boron from the Koralpe, Styria, Austria. Österreichische Akademie Der Wissenschaften, Mathematisch-Naturwissenschaftliche Klasse, Abt. I, Anzeiger, 134, 3-10.

Ertl, A., Hughes, J.M., Pertlik, F., Foit, F.F. Jr., Wright, S.E., Brandstätter, F., and Marler, B. (2002) Polyhedron distortions in tourmaline. Canadian Mineralogist, 40, 153-162. https://doi.org/10.2113/gscanmin.40.1.153.

Ertl, A., Hughes, J.M., Brandstätter, F., Dyar, M.D., and Prasad, P.S.R. (2003) Disordered Mg-bearing olenite from a granitic pegmatite at Goslarn, Austria: A chemical, structural and infrared spectroscopic study. Canadian Mineralogist, 41, 1363-1370. https://doi.org/10.2113/gscanmin.41.6.1363.

Ertl, A., Schuster, R., Prowatke, S., Brandstätter, F., Ludwig, T., Bernhardt, H.-J., Koller, F., and Hughes, J.M. (2004) Mn-rich tourmaline and fluorapatite in a Variscan pegmatite from Eibenstein an der Thaya, Bohemian massif, Lower Austria. European Journal of Mineralogy, 16, 551-560. doi:10.1127/09351221/2004/0016-0551.

Ertl, A., Rossmann, G.R., Hughes, J.M., Prowatke, S., and Ludwig, T. (2005) Mn-bearing "oxy-rossmanite" with tetrahedrally coordinated Al and B from Austria: Structure, chemistry, and infrared and optical spectroscopic study. American Mineralogist, 90, 481-487. https://doi.org/10.2138/am.2005.1683.

Ertl, A., Hughes, J.M., Prowatke, S., Ludwig, T., Brandstätter, F., Körner, W., and Dyar, M.D. (2007) Tetrahedrally-coordinated boron in Li-bearing olenite from "mushroom" tourmaline from Momeik, Myanmar. Canadian Mineralogist, 45, 891-899. https://doi.org/10.2113/gscanmin.45.4.891.

Ertl, A., Tillmanns, E., Ntaflos, T., Francis, C., Giester, G., Körner, W., Hughes, J.M., Lengauer, C., and Prem, M. (2008) Tetrahedrally coordinated boron in Al-rich tourmaline and its relationship to the pressure-temperature conditions of formation. European Journal of Mineralogy, 20, 881-888. doi:10.1127/09351221/2008/0020-1869.

Ertl, A., Kolitsch, U., Meyer, H.-P., Ludwig, T., Lengauer, C.L., Nasdala, L., and Tillmanns, E. (2009) Substitution mechanism in tourmalines of the fluor-elbaite-rossmanite series from Wolkenburg, Saxony, Germany. Neues Jahrbuch Für Mineralogie Abhandlungen, 186, 51-61. doi:10.1127/00777757/2009/0136.

Ertl, A., Rossman, G.R., Hughes, J.M., London, D., Wang, Y., O’Leary, J.A., Dyar, M.D., Prowatke, S., Ludwig, T., and Tillmanns, E. (2010) Tourmaline of the elbaite-schorl series from the Himalaya Mine, Mesa Grande, California, U.S.A. American Mineralogist, 95, 24 40. https://doi.org/10.2138/am.2010.3271.

Ertl, A., Giester, G., Ludwig, T., Meyer, H.-P., and Rossman, G.R. (2012a) Synthetic B-rich olenite: Correlations of single-crystal structural data. American Mineralogist, 97, 1591-1597. https://doi.org/10.2138/am.2012.4060.

Ertl, A., Kolitsch, U., Dyar, M.D., Hughes, J.M., Rossman, G.R., Pieczka, A., Henry, D.J., Pezzotta, F., Prowatke, S., Lengauer, C.L., and others (2012b) Limitations of $\mathrm{Fe}^{2+}$ and $\mathrm{Mn}^{2+}$ site occupancy in tourmaline: evidence from $\mathrm{Fe}^{2+}$ - and $\mathrm{Mn}^{2+}$-rich tourmaline. American Mineralogist, 97, 1402-1416. https:// doi.org/10.2138/am.2012.4028.

Ertl, A., Giester, G., Schüssler, U., Brätz, H., Okrusch, M., Tillmanns, E., and Bank, H. (2013) Cu- and Mn-bearing tourmalines from Brazil and Mozambique: Crystal structures. Mineralogy and Petrology, 107, 265-279. https:// doi.org/10.1007/s00710-012-0234-6.

Ertl, A., Vereshchagin, O.S., Giester, G., Tillmanns, E., Meyer, H.-P., Ludwig, T., Rozhdestvenskaya, I.V., and Frank-Kamenetskaya, O.V. (2015) Structural 
and chemical investigation of a zoned synthetic $\mathrm{Cu}$-rich tourmaline. Canadian Mineralogist, 53, 209-220. https://dx.doi.org/10.3749/canmin.1400078.

Ertl, A., Henry, D.J., and Tillmanns, E. (2018) Tetrahedral substitutions in tourmaline: A review. European Journal of Mineralogy, 30, 465-470. doi:10.1127/ ejm/2018/0030-2732.

Ertl, A., Hughes, J.M., Prowatke, S., Ludwig, T., Lengauer, C.L., and Meyer, H.-P. (2020) Alumino-oxy-rossmanite, IMA 2020-008b. CNMNC Newsletter 58. European Journal of Mineralogy, 32, 651.

Foit, F.F. Jr. (1989) Crystal chemistry of alkali-deficient schorl and tourmaline structural relationships. American Mineralogist, 74, 422-431.

Foit, F.F. Jr., and Rosenberg, P.E. (1979) The structure of vanadium-bearing tourmaline and its implications regarding tourmaline solid solutions. American Mineralogist, 64, 788-798.

Götzinger, M.A., Beran, A., and Libowitzky, E. (1994) Exkursion A: Mineralvorkommen und Lagerstätten im östlichen Waldviertel. Mitteilungen Der Österreichischen Mineralogischen Gesellschaft, 139, 389-405.

Grew, E.S., Chernosky, J.V., Werding, G., Abraham, K., Marquez, N., and Hinthorne, J.R. (1990) Chemistry of kornerupine and associated minerals, a wet chemical, ion microprobe, and X-ray study emphasizing Li-contents, Be-contents, B-contents and F-contents. Journal of Petrology, 31, 1025-1070. https://doi.org/10.1093/petrology/31.5.1025.

Grew, E.S., Yates, M.G., Shearer, C.K., and Wiedenbeck, M. (1997) Werdingite from the Urungwe district. Mineralogical Magazine, 61, 713-718. doi:10.1180/ minmag.1997.061.408.11.

Hawthorne, F.C. (1996) Structural mechanisms for light-element variations in tourmaline. Canadian Mineralogist, 34, 123-132.

(2002) Bond-valence constraints on the chemical composition of tourmaline. Canadian Mineralogist, 40, 789-797. http://dx.doi.org/10.2113/ gscanmin.40.3.789.

(2016) Short-range atomic arrangements in minerals. I: The minerals of the amphibole, tourmaline and pyroxene supergroups. European Journal of Mineralogy, 28, 513-536. doi:10.1127/ejm/2016/0028-2538.

Hawthorne, F.C., and Henry, D.J. (1999) Classification of the minerals of the tourmaline group. European Journal of Mineralogy, 11, 201-215. doi:10.1127/ $\mathrm{ejm} / 11 / 2 / 0201$.

Hawthorne, F.C., MacDonald, D.J., and Burns, P.C. (1993) Reassignment of cation site-occupancies in tourmaline: Al-Mg disorder in the crystal structure of dravite. American Mineralogist, 78, 265-270.

Henry, D.J., and Dutrow, B.L. (1996) Metamorphic tourmaline and its petrologic applications. Reviews in Mineralogy and Geochemistry, 33, 503-557.

Henry, D.J., Novák, M., Hawthorne, F.C., Ertl, A., Dutrow, B.L., Uher, P., and Pezzotta, F. (2011) Nomenclature of the tourmaline-supergroup minerals. American Mineralogist, 96, 895-913. https://doi.org/10.2138/am.2011.3636.

Hinton, R.W. (1990) Ion microprobe trace-element analysis of silicates: Measurement of multi-element glasses. Chemical Geology, 83, 11-25. https://doi. org/10.1016/0009-2541(90)90136-U.

(1995) Ion microprobe analysis in geology. In P.J. Potts, J.F.W. Bowles, S.J.B. Reed, and R.M. Cave, Eds., Microprobe Techniques in the Earth Sciences, p. 235-289. Cambridge University Press.

Huebner, J.S. (1969) Stability relations of rhodochrosite in the system manganesecarbon-oxygen. American Mineralogist, 54, 457-481.

Hughes, J.M., Ertl, A., Dyar, M.D., Grew, E.S., Shearer, C.K., Yates, M.G., and Guidotti, C.V. (2000) Tetrahedrally coordinated boron in a tourmaline: Boronrich olenite from Stoffhütte, Koralpe, Austria. Canadian Mineralogist, 38, 861-868. http://dx.doi.org/10.2113/gscanmin.38.4.861.

Hughes, J.M., Ertl, A., Dyar, M.D., Grew, E.S., Wieden-Beck, M., and Brandstätter, F. (2004) Structural and chemical response to varying ${ }^{[4]}$ B content in zoned Fe-bearing olenite from Koralpe, Austria. American Mineralogist, 89, 447-454. https://doi.org/10.2138/am-2004-2-326.

Hughes, J.M., Rakovan, J., Ertl, A., Rossman, G.R., Baksheev, I., and Bernhardt, H.-J. (2011) Dissymetrization in tourmaline: The atomic arrangement of sectorally zoned triclinic Ni-bearing dravite. Canadian Mineralogist, 49, 29-40. http://dx.doi.org/10.3749/canmin.49.1.29.

Kolitsch, U., Löffler, E., Schillhammer, H., Knobloch, G., and Lamatsch, P. (2020) Baryt, Bertrandit, Columbit-(Mn), Eulytin, Hübnerit, rosa Olenit, Pezzottait(?), Pollucit, Rutil, Scheelit, Stibarsen, "Uranmikrolith" und gediegen Wismut sowie ein neues Cs-Al-Phosphat in einem rosa Turmaline enthaltenden Pegmatit im Steinbruch von Eibenstein im Waldviertel, Niederösterreich: ein Vorbericht, p. 191-200. In Walter, F et al., Neue Mineralfunde aus Österreich LXIX. Carinthia II, 210./130., 153-218.

Ksanda, C.J., and Merwin, H.E. (1939) Improved technique in micropycnometric density determination. American Mineralogist, 24, 482-484.

Lindner, M., Dörr, W., Reither, D., and Finger, F. (2020) The Dobra Gneiss and the Drosendorf Unit in the southeastern Bohemian Massif, Austria: West Amazonian crust in the heart of Europe. Geological Society, London, Special Publications, 503, 185-207.

Ludwig, T., and Stalder, R. (2007) A new method to eliminate the influence of in situ contamination in SIMS analysis of hydrogen. Journal of Analytical Atomic Spectrometry, 22, 1415-1419. https://doi.org/10.1039/B705848A.

Lussier, A.J., Aguiar, P.M., Michaelis, V.K., Kroeker, S., and Hawthorne, F.C. (2009) The occurrence of tetrahedrally coordinated $\mathrm{Al}$ and B in tourmaline: $\mathrm{An}{ }^{11} \mathrm{~B}$ and ${ }^{27}$ Al MAS NMR study. American Mineralogist, 94, 785-792. https://doi.org/ 10.2138/am.2009.3000.

MacDonald, D.J., and Hawthorne, F.C. (1995) The crystal chemistry of Si $\leftrightarrow \mathrm{Al}$ substitution in tourmaline. Canadian Mineralogist, 33, 849-858.

Mattson, S.M. (1985) Optical expressions of ion-pair interactions in minerals. $\mathrm{Ph}$.D. thesis, California Institute of Technology, Pasadena.

Novák, M., Ertl, A., Povondra, P., Galiová, M.V., Rossman, G.R., Pristacz, H., Prem, M., Giester, G., Gadas, P., and Škoda, R. (2012) Darrellhenryite, $\mathrm{NaLiAl}_{2} \mathrm{Al}_{6}\left(\mathrm{BO}_{3}\right)_{3} \mathrm{Si}_{6} \mathrm{O}_{18}(\mathrm{OH})_{3} \mathrm{O}$, a new mineral from the tourmaline supergroup. American Mineralogist, 98, 1886-1892. https://doi.org/10.2138/ am.2013.4416

Ottolini, L., Bottazzi, P., and Vannucci, R. (1993) Quantification of lithium, beryllium, and boron in silicates by secondary ion mass spectrometry using conventional energy filtering. Analytical Chemistry, 65, 1960-1968. https:// doi.org/10.1021/ac00063a007.

Pearce, N.J.G., Perkins, W.T., Westgate, J.A., Gorton, M.P., Jackson, S.E., Neal, C.R., and Chenery, S.P. (1997) A compilation of new and published major and trace element data for NIST SRM 610 and SRM 612 partially certified glass reference materials. Geostandards and Geoanalytical Research, 21, 115-144. https://doi.org/10.1111/j.1751-908X.1997.tb00538.x.

Petrakakis, K. (1997) Evolution of Moldanubian rocks in Austria: Review and synthesis. Journal of Metamorphic Geology, 15, 203-222. https://doi.org/ 10.1111/j.1525-1314.1997.00015.x.

Pouchou, J.-L., and Pichoir, F. (1991) Quantitative analysis of homogeneous or stratified microvolumes applying the model "PAP". In K.F.J. Heinrich and D.E. Newbury, Eds., Electron Probe Quantitation, pp. 31-75. Plenum Press.

Povondra, P., and Čech, A. (1976) A method for the chemical analysis of tourmaline. Acta Universitatis Carolinae Geologica, 209-218.

Povondra, P., Čech, F., and Staněk, J. (1985) Crystal chemistry of elbaites from some pegmatites of the Czech Massif. Acta Universitatis Carolinae, Geologica, 1-24.

Reinitz, I.L., and Rossman, G.R. (1988) Role of natural radiation in tourmaline coloration. American Mineralogist, 73, 822-825.

Selway, J.B., Novák, M., Hawthorne, F., Černý, P., Ottolini, L., and Kyser, T.K. (1998) Rossmanite, $\square\left(\mathrm{LiAl}_{2}\right) \mathrm{Al}_{6}\left(\mathrm{Si}_{6} \mathrm{O}_{18}\right)\left(\mathrm{BO}_{3}\right)_{3}(\mathrm{OH})_{4}$, a new alkali-deficient tourmaline: Description and crystal structure. American Mineralogist, 83, 896-900. https://doi.org/10.2138/am-1998-7-822.

Schreyer, W., Hughes, J.M., Bernhardt, H.-J., Kalt, A., Prowatke, S., and Ertl, A. (2002) Reexamination of olenite from the type locality: detection of boron in tetrahedral coordination. European Journal of Mineralogy, 14, 935-942.

Sheldrick, G.M. (2002) SADABS Area-Detector Absorption Correction Program. Bruker Axs Inc.

(2008) A short history of SHELX. Acta Crystallographica, A64, 112-122. https://doi.org/10.1107/S0108767307043930.

Sokolov, P.B., Gorskaya, M.G., Gordienko, V.V., Petrova, M.G., Kretser, Yu.L., and Frank-Kamenetskii, V.A. (1986) Olenite, $\mathrm{Na}_{1-\mathrm{x}} \mathrm{Al}_{3} \mathrm{Al}_{6} \mathrm{~B}_{3} \mathrm{Si}_{6} \mathrm{O}_{27}(\mathrm{O}, \mathrm{OH})_{4}$, a new high-alumina mineral of the tourmaline group. Zapiski Vsesoyuznogo Mineralogicheskogo Obshchestva, 115, 119-123.

Sorger, D. (2020) Metamorphic and tectonic evolution of the Drosendorf and Gföhl units - Lower Austria, Bohemian Massif. Dissertation, Karl-FranzensUniversität Graz, Graz, Austria, 127 pp.

Syromyatnikov, F.V. (1935) The micropycnometric method for the determination of specific gravities of minerals. American Mineralogist, 20, 364-370.

Van Hinsberg, V.J., and Schumacher, J.C. (2007) Using estimated thermodynamic properties to model accessory phases: the case of tourmaline. Journal of Metamorphic Geology, 25, 769-779. https://doi.org/10.1111/j. 1525-1314.2007.00728.x.

Van Hinsberg, V.J., Henry, D.J., and Dutrow, B.L. (2011) Tourmaline as a petrologic forensic mineral: A unique recorder of its geologic past. Elements, 7, 327-332. https://doi.org/10.2113/gselements.7.5.327.

MANUSCRIPT RECEIVED MARCH 7, 2021

MANUSCRIPT ACCEPTED JUNE 17, 2021

MANUSCRIPT HANDLED BY EDWARD S. GREW

\section{Endnote:}

${ }^{1}$ Deposit item AM-22-28047, Online Materials. Deposit items are free to all readers and found on the MSA website, via the specific issue's Table of Contents (go to http:// www.minsocam.org/MSA/AmMin/TOC/2022/Feb2022_data/Feb2022_data.html). The CIF has been peer reviewed by our Technical Editors. 